\title{
A revision of the genus Gouania (Rhamnaceae) in the Philippines and Sundaland
}

\author{
Daniel Cahen ${ }^{1}$, Kurt S. Stenn ${ }^{2}$ \& Timothy M. A. Utteridge ${ }^{1}$
}

Summary. The climbing genus Gouania (Rhamnaceae) is revised in western Malesia. Five species are recognised for the Philippines and Sundaland using morphological evidence, including a new species from the Philippines: Gouania longipedunculata. A taxonomic treatment, including a preliminary IUCN conservation status assessment, is presented for each species.

Key Words. conservation, IUCN, Malesia, South-East Asia, systematics, taxonomy, tropical climbers.

\section{Introduction}

Gouania Jacq. is a pantropical genus of over 50 species of woody climbers, recognised by having circinnate tendrils and 3-winged dry schizocarps separating into three 2-winged indehiscent mericarps (Medan \& Schirarend 2004). The genus belongs to the monophyletic tribe Gouanieae, first formally described by Endlicher (1840) and confirmed to be monophyletic by Richardson et al. (2000a, b). Gouania and Helinus E.Mey. ex Endl. are the only members of the tribe occurring in the Old World. Helinus species are also climbers with tendrils, but their fruits are unwinged explosive capsules and are restricted to Eastern and Southern Africa, Madagascar, the southern end of the Arabian Peninsula and the Indian subcontinent. Gouania alone is found in the Philippines and Sundaland. As noted by Medan \& Schrirarend (loc. cit.), the genus needs revision, but recent headway has been made with revisions for the Western Indian Ocean (Buerki et al. 2011) and North America (Pool 2014). Most of the c. 15 South-East Asian genera of Rhamnaceae, and the climbing genera in particular, have yet to be revised and included in contemporary floras such as Flora Malesiana or the Flora of Peninsular Malaysia, although a synopsis of Smythea (Cahen \& Utteridge 2018) and a key to the Bornean species of Ventilago (Cahen \& Utteridge 2017) were recently published. The most complete overview of Asian Gouania species to date is by Lauterbach (1922), with some minor changes by Suessenguth (1953) in the last attempt at a complete treatment at species level.

While Sundaland's phytogeographical boundaries differ according to sources and the distribution of a single species is often at odds with general patterns (van Steenis 1950), the area delimited by Woodruff (2003) shares the same northwestern and southeastern limits as the distribution of Gouania obtusifolia, with limits just north of the Isthmus of Kra on the Malay Peninsula and immediately east of Java, and is used here to define the extent of the study area for Sundaland. The taxonomic history of the genus in Sundaland is complex and best understood by starting with Java as more literature is available for this area. Blume (1826) recognised two species that had originally been described from Réunion: G. tiliaefolia Lam. [G. tiliifolia Lam.] and G. mauritiana Lam. The same year, Brongniart (1826) described G. obtusifolia Vent. ex Brongn., a new species based on material in Ventenats's herbarium collected in Java. Miquel (1856) seems to have been unaware of Brongniart's species when he described G. javanica Miq., and also treated G. tiliaefolia sensu Blume non Lam. as a synonym of G. leptostachya DC. and listed G. microcarpa DC. and G. retinaria DC. as additional species for the island. Gouania microcarpa however is restricted to India and Sri Lanka, as noted by King (1896), and G. retinaria is a synonym of G. scandens (Gaertn.) R.B.Drumm., which is only known to occur in the Western Indian Ocean (Buerki et al. 2011). Backer \& Bakhuizen van der Brink (1965) recognised only G. javanica and G. leptostachya for Java. Study of herbarium material supports this view, although G. javanica is placed here in the synonymy of G. obtusifolia. The same two species found in Java occur in Peninsular Malaysia as was recognised by King (loc. cit.) and Ridley (1922) and are the only Gouania species known to occur there. Confusingly, the name G. javanica has also been extensively used to refer to plants observed in southern China and throughout SE Asia (Chen \& Schirarend 2007; Pitard 1907 - 1912; Wilson 1916). Plants identified as G. javanica collected north of the Malay Peninsula differ from G. obtusifolia but are best referred as G. brandisii Hassk. (discussed below in Notes for G. obtusifolia). Little could be found about the genus

Accepted for publication 4 February 2020. Published online 2 May 2020

1 Herbarium, Royal Botanic Gardens, Kew, Richmond, Surrey, TW9 3AE, UK. e-mail: d.cahen@kew.org

2 Department of Plant Biology, School of Environmental and Biological Sciences, Rutgers University, New Brunswick, NJ, 08901-8520, USA. 
in Sumatra; Gouania is not included in Prodromus florae Sumatranae (Miquel 1860), but Suessengueth (1953) mentions both $G$. javanica (= G. obtusifolia) and G. leptostachya as occurring on the island.

The Philippine and Malaysian floras are closely related (van Steenis loc. cit.) and both areas are included in a recognised Sunda Shelf and Philippines bioregion (Wikramanayake et al. 2002). While two species included here are Philippine endemics, G. nematostachya straddles both Sundaland and the Philippines and the genus is advantageously studied for both areas together. Blanco (1837) originally presented G. domingensis (Jacq.) L. as the only species of the genus occurring in the Philippines. Gouania domingensis sensu Blanco, non L. was later treated as a synonym of $G$. leptostachya by Fernández-Villar (1880) in Novissima Appendix to Blanco's Flora. Gouania microcarpa was later recognised as an additional species of the Philippines by Rolfe (1885), who noted that nearly all plants included in the Novissima Appendix were based on descriptions of species from India and the Malay Archipelago, resulting in an underestimation of the number of endemic species. Following Rolfe's publication, $G$. domingensis sensu Blanco, non L. and G. leptostachya sensu Fern.-Vill., non DC. were placed as synonyms of G. microcarpa by Vidal (1886) and Merrill (1918), resulting in a single recognised species for the Philippines. Merrill (1923) then placed G. microcarpa in synonymy under G. tiliaefolia and recognised G. javanica as an additional species for Luzon, Polillo, Mindoro, Leyte and Mindanao. Lauterbach (1922) did not consider G. tiliaefolia and G. javanica to occur in the Philippines and described two endemic new species: G. fimbriata Reissek ex Lauterb. and G. nematostachya Reissek ex Lauterb., and both species were retained by Suessengueth (1953) and are recognised here as distinct species after study of herbarium material. Gouania nematostachya also occurs in Sulawesi and Borneo. It is the only species of Gouania known to grow in Borneo, where it was identified as G. microcarpa by several authors, e.g. Merrill 1921, Masamune 1942, Beaman \& Anderson 2004, but differs from G. microcarpa in several morphological characters (discussed below in Notes for G. nematostachya). Specimens from Philippine islands south of Luzon, with densely hairy leaves and peduncles longer than in G. fimbriata, are described here as belonging to a new species: $G$. longipedunculata.

\section{Material and Methods}

Herbarium specimens from BKF, E, GH, K and L were studied and measurements with additional digital images studied from A, E, G, L, M, NY, P, U, S, W, WAG and WRSL; an exclamation mark (!) is used to show that a specimen has been seen and barcodes are given for type information where there could be confusion. An alphabetical index to all numbered collections examined is given at the end of the paper (Appendix 1). Material was examined under a Zeiss Stemi 1000 binocular microscope at magnifications of up $\times 350$. Leaf anatomy terms used are from Hickey (1979). Leaf measurements were made on branchlet leaves inserted proximally to the racemiform inflorescences, rather than leaves inserted along the racemiform inflorescence rachis. The terminology used to describe stipules follows Pool (2014). Hair density terms are defined as follows: sparse when hairs are scattered enough not to touch when pressed towards each other, abundant when hairs are close enough to touch if pressed towards each other, dense when hairs are so close to each other that they hide the surface of the organ they grow on. Inflorescences are described here as racemiform thyrses because they superficially resemble racemes, with the cymes inserted along a well-developed, unbranched axis. Fruit measurements follow Pool (loc. cit.), but only on fruit mature enough to be at dispersal, i.e. splitting, or on free mericarps; pedicels were also measured at the mature fruit stage. Other morphology terms follow Beentje (2010). Climber length, basal diameter, flower colour and fragrance information were retrieved from herbarium specimen labels. Habitat names used in species accounts are based on the Ecoregions 2017 map (Dinerstein et al. 2017). Localities and collection dates were inferred where possible using the Cyclopaedia of Malesian Collectors (van Steenis-Kruseman 2017) but coordinates are not given for localities when uncertainty or imprecision is too great. Conservation assessments in species accounts apply IUCN Red List categories and criteria (IUCN 2012), using GeoCat (Bachman et al. 2011) to calculate Extent of Occurrence (EOO) metrics. Protected areas were located using the World Database on Protected Areas online interface (IUCN \& UNEP-WCMC 2018).

\section{Key morphological characters}

\section{Leaves}

Gouania species all have simple, alternate, petiolate leaves. Glands and foliaceous appendages are often present along the petiole, especially near the junction with the leaf blade. Glands are also usually present along the leaf margin, with one gland associated to each serration when serrations are present. Leaves vary in shape on the same plant. A consistent pattern noted by Lauterbach (1922) is for proximal leaves to be cordate and distal leaves to be cuneate to rounded at the base. All Philippine and Sundaland species of Gouania can be recognised by observing leaf features only. Gouania leptostachya stands out by being the only species with $4-5$ pairs of secondary veins and sunken marginal glands (Fig. 1B). Other species have leaves with $5-6(-7)$ pairs of secondary veins and protruding marginal glands. Gouania leptostachya leaves are also completely glabrous except along veins. The only other species that sometimes has glabrous leaves is G. fimbriata, which is only known from Luzon and where G. leptostachya is unrecorded. Gouania nematostachya is unique in having up to 50 small serrations along the leaf 
margins (Fig. 1C). Other species have leaves with up to 30 serrations along the margin. A foliaceous appendage or tufts of hairs (domatia) are often present in axils of veins in G. fimbriata, G. longipedunculata and G. obtusifolia (Fig. 1D). Of the three, G. obtusifolia is the only species with conspicuous crenations all along the leaf margin. Gouania longipedunculata leaves are abundantly to densely hairy when mature (Fig. 2D \& E), unlike the glabrous to sparsely hairy leaves of G. fimbriata. The leaf blade apex is rounded to acute in G. obtusifolia, acute to attenuate (-acuminate) in $G$. fimbriata and $G$. longipedunculata and attenuate to acuminate in G. leptostachya and G. nematostachya.

\section{Stipules}

Stipules are soon fugaceous for all Gouania species from the region and are visible in just a small proportion of herbarium specimens from that area. They are usually lost by anthesis and are most easily observed remaining near the apical meristem of developing shoots. Only in G. fimbriata, and to a certain extent $G$. longipedunculata, are stipules frequently retained at anthesis. Reissek (1861), and especially Pool (2014), recognised the diagnostic usefulness of stipules for identification of American Gouania species. Stipules are also useful to recognise Asian species. They are deeply pinnatifid and up to $8 \mathrm{~mm}$ long in G. fimbriata, pinnatifid and up to $7 \mathrm{~mm}$ in G. longipedunculata (Fig. 2F \& $\mathrm{G})$, entire to slightly pinnatifid and c. $6 \mathrm{~mm}$ long in G. obtusifolia, entire and c. $2.5 \mathrm{~mm}$ long in G. nematostachya. The only species of this region that has stipules with a lobule at the base is G. leptostachya. The upper portion of the stipule is entire and c. $4 \mathrm{~mm}$ long; the lobule diverges at c. $120^{\circ}$ from the upper portion and is c. $1 \mathrm{~mm}$ long (Fig. 1A).

\section{Disk and disk lobes}

Disks of Gouania flowers provide especially useful diagnostic characters and have been extensively used in dichotomous keys (Reissek 1861; Lauterbach 1922; Suessenguth 1953; Buerki et al. 2011; Pool 2014) and are helpful to identify
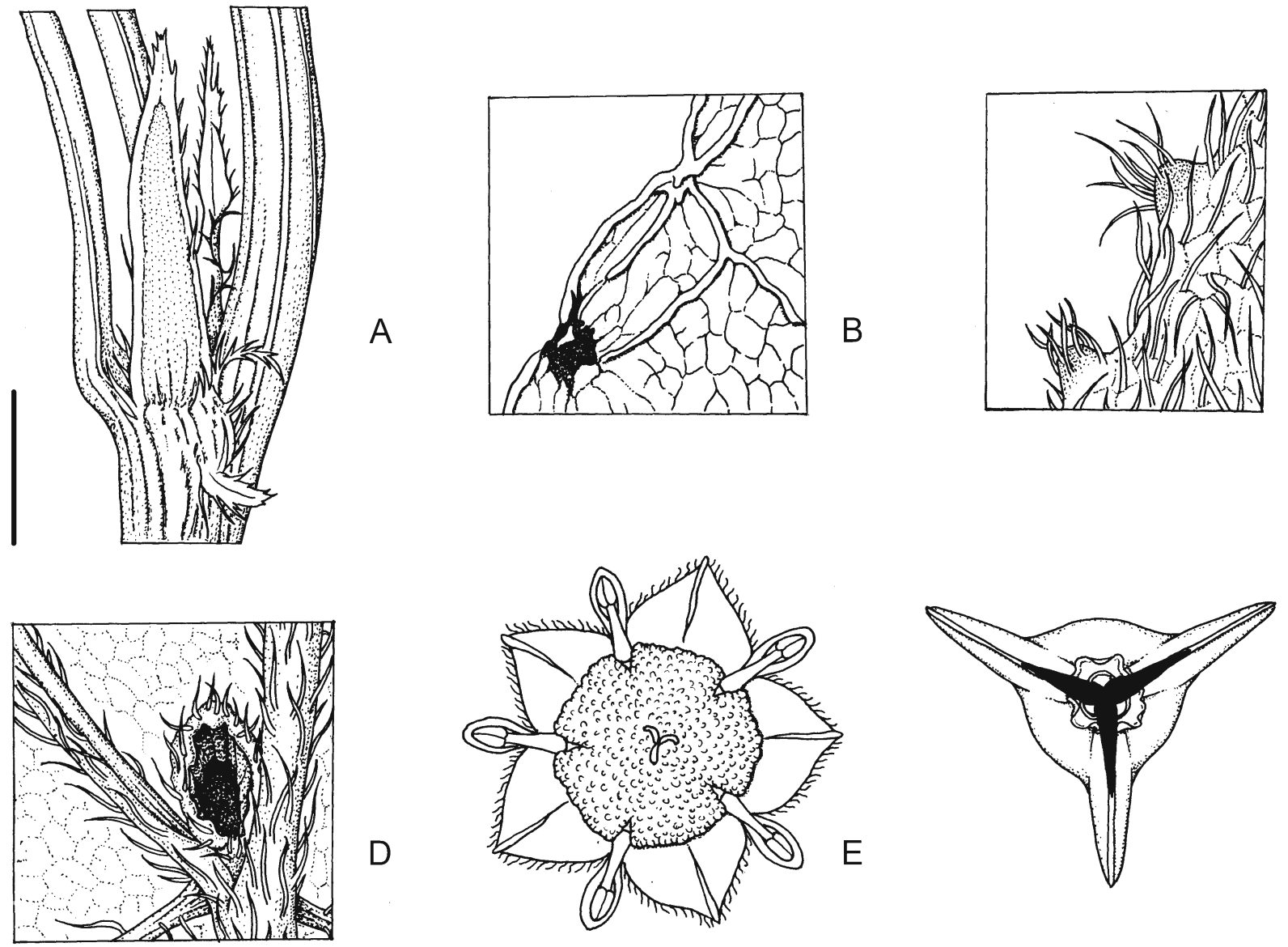

$\mathrm{F}$

Fig. 1. Morphological characters in Gouania species of the Philippines and Sundaland. A stipule of G. leptostachya; B detail of leaf margin of $G$. leptostachya, abaxial view; $C$ detail of leaf margin of $G$. nematostachya, adaxial view; $\mathbf{D}$ detail of domatia of G. obtusifolia; E flower of G. nematostachya, opened flat, apical view; F fruit of G. leptostachya, splitting, apical view. Scale bar: A, $E=2$ mm; B - D = 4 mm; F = 5 mm. A, F from Lörzing 13270; B from s.c. s.n. [Java, K001293563]; C from Duaneh 429; D from Teo \& Pachiappan 221; E from Clemens 26263. DRAWN BY NAOKO YASUE. 
Philippine and Sundaland species. In all known Asian Gouania species, nectar disks are fleshy and fill most of the hypanthium above the ovary and around the exserting trifid style. The central portion of the disk, called the annulus (following Pool 2014), often forms a sheath around the style, especially in G. fimbriata, G. longipedunculata and G. obtusifolia. Weak ridges are sometimes visible on the disk surface, radiating from the annulus. The surface is glabrous in all Malesian species, smooth in G. fimbriata, G. longipedunculata and $G$. obtusifolia, smooth to rugulose (weakly wrinkled) in G. leptostachya and rugose (wrinkled) in G. nematostachya (Fig. 1E). Narrow disk lobes opposite the sepals are present in many species of Gouania worldwide, including all species of the Philippines and Sundaland except G. nematostachya. The disk lobes are tapering in G. fimbriata, G. longipedunculata (Fig. 2K) and G. obtusifolia, unlike in G. leptostachya, which has disk lobes with parallel sides as noted by Lauterbach (1922) and Suessenguth (1953). It is often possible to observe the presence of disk lobes and determine whether the disk is smooth or rugose by looking at the flower remains at the distal end of fruits.

\section{Fruit}

The mature fruit provides diagnostic characters for several taxa from North America (Pool 2014) and the Western Indian Ocean (Buerki et al. 2011), and is also useful for the identification of Philippine and Sundaland species. What is referred to here as mature is when mericarps can be found splitting from each other (Fig. 1F). This definition is not completely satisfactory because some fruits with not fully developed wings can occasionally be seen splitting on herbarium specimens (Cahen \& Stenn pers. obs.). When immature, fruits are obovoid and unwinged (Fig. 2H). The inferior ovary dries with a darker colour than the persisting sepal lobes, giving the impression it might mature into a fleshy fruit. As fruits develop however, the mericarp wings expand, both laterally and vertically (Fig. 2N). Gouania leptostachya has significantly bigger fruits than all other species of the region, with a fruit body (the medial portion of the mericarp where the seed is enclosed) c. $8 \mathrm{~mm}$ high and mericarps $10-16 \mathrm{~mm}$ wide (Fig. 1F). Fruit bodies are c. $4 \mathrm{~mm}$ high in G. fimbriata, G. longipedunculata (Fig. 2N) and G. obtusifolia, and c. $5 \mathrm{~mm}$ high in G. nematostachya. Their mericarps are $9-12 \mathrm{~mm}$ wide. The fruit body also tends to be sparsely hairy and to dry with a darker colour than the mericarp wings in these species, unlike G. leptostachya, which has a glabrous fruit body that dries with the same colour as the mericarp wings. Gouania nematostachya fruits are slightly smaller and have more of a "bowtie shape" (terminology from Pool 2014), with a smaller height/width ratio than all other species of the region. Note that peduncles and pedicels can easily be confused when examining Gouania specimens. Peduncles are persistent after fruit dispersal and bear scars where the pedicels were inserted. The only species in this region with strongly developed peduncles are G. fimbriata (to $4 \mathrm{~mm}$ long) and $G$. longipedunculata (to $8 \mathrm{~mm}$ long).

\section{Taxonomic Treatment}

\section{Key to Gouania species for the Philippines and Sundaland}

1. Leaf margin densely, finely serrate with usually $40-50$ serrations on either side. Flower nectar disk unlobed, disk surface wrinkled $\ldots \ldots \ldots \ldots \ldots \ldots \ldots \ldots \ldots \ldots \ldots \ldots \ldots$ Gouania nematostachya

Leaf margin subentire, crenate or crenate-serrate with up to 30 serrations on either side. Flower nectar disk stellate, with five narrow lobes opposite the sepals, similar in appearance to stamen filaments, disk surface

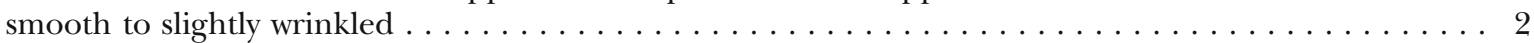

2. Leaf margin crenate, with up to 30 serrations on either side, marginal glands sunken inside serrations; domatia in axils of secondary veins absent; secondary veins $4-5$ pairs; lamina surface glabrous abaxially except along veins. Stipules with a basal lobule pointing sideways. Thyrses to $35 \mathrm{~cm}$ long; bracts entire, c. $2.5 \mathrm{~mm}$ long, glabrous. Fruiting pedicel to $2.5 \mathrm{~mm}$ long, sparsely hairy. Fruit body c. $8 \mathrm{~mm}$ high, same colour as wings; mericarps $10-16 \mathrm{~mm}$ wide. Seeds $4 \times 4 \mathrm{~mm} \ldots \ldots \ldots \ldots$. . . . . Gouania leptostachya

Leaf margin subentire to crenate, with usually 15 - 20 serrations on either side, marginal glands protruding; domatia in axils of secondary veins often present; secondary veins $5-6(-8)$ pairs; lamina surface glabrous to densely hairy abaxially. Stipules simple. Thyrses to $25 \mathrm{~cm}$ long; bracts entire to deeply divided, $3-6 \mathrm{~mm}$ long, densely hairy. Fruiting pedicel to $1 \mathrm{~mm}$ long, densely hairy. Fruit body c. $4 \mathrm{~mm}$ high, darker than wings, mericarps $9-12 \mathrm{~mm}$ wide. Seeds to $3 \times 2.5 \mathrm{~mm} \ldots \ldots \ldots \ldots \ldots \ldots$

3. Leaf margin conspicuously crenate; apex rounded to acute. Stipules soon fugaceous. Cymes sessile. Seeds $2 \times 2$ $\operatorname{mm} \ldots \ldots \ldots \ldots \ldots \ldots \ldots \ldots \ldots \ldots \ldots \ldots \ldots \ldots \ldots$. Gouania obtusifolia

Leaf margin weakly serrate, subentire in proximal $1 / 3$, apex usually attenuate. Stipules often persisting to anthesis. Cymes usually pedunculate. Seeds to $3 \times 2.5 \mathrm{~mm} \ldots \ldots \ldots \ldots \ldots$

4. Leaf surface glabrous to sparsely hairy abaxially when mature. Peduncles $1-4 \mathrm{~mm}$ long. . . 1. Gouania fimbriata Leaf surface abundantly to very densely hairy abaxially when mature. Peduncles to $8 \mathrm{~mm}$ long . . . . . . .

$\ldots \ldots \ldots \ldots \ldots \ldots \ldots \ldots \ldots \ldots \ldots \ldots \ldots \ldots \ldots$. Gouania longipedunculata $\mathrm{sp}$ nov. 


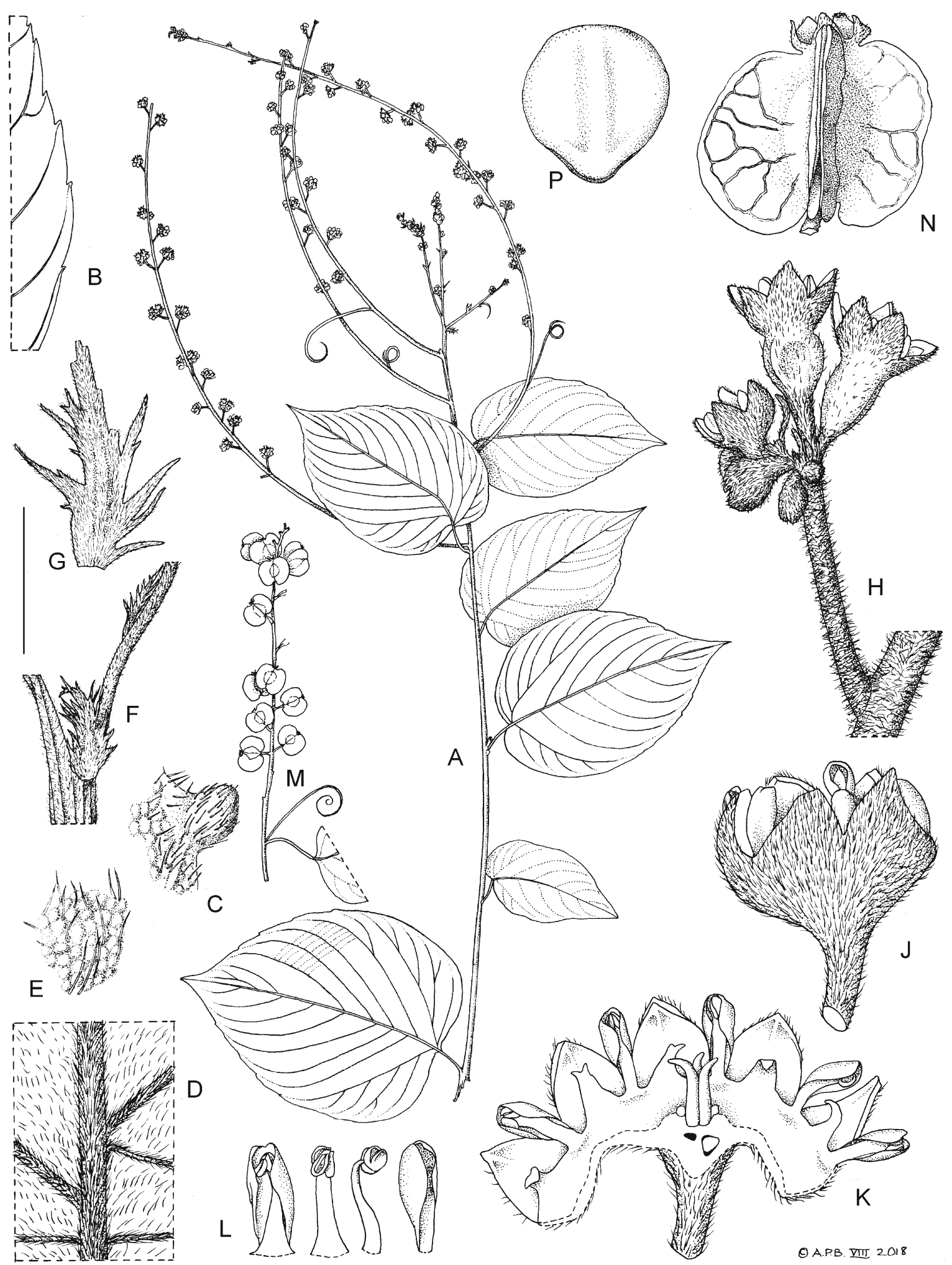

Fig. 2. Gouania longipedunculata. A habit; B leaf margin, abaxial view; C detail of leaf serration; D detail of leaf indumentum, abaxial view; E detail of leaf surface, abaxial view; F stipule and inflorescence rachis with a bract; $\mathbf{G}$ stipule, adaxial view; $\mathrm{H}$ pedunculate cyme with flowers in bud and open; J flower, lateral view; K flower cut and opened flat, ovary part-sectioned; $L$ petal enclosing stamen and isolated stamen, abaxial, side and 3/4 view (left to right); $\mathbf{M}$ infructescence; $\mathrm{N}$ fruit, lateral view; $\mathbf{P}$ seed, ventral view. Scale bar: $A=5.3 \mathrm{~cm} ; B=1 \mathrm{~cm} ; C, E=0.9 \mathrm{~mm} ; \mathrm{F}, \mathrm{H}=3.7 \mathrm{~mm} ; \mathrm{G}, \mathrm{N}=5 \mathrm{~mm} ; \mathrm{J}, \mathrm{K}=1.6 \mathrm{~mm} ; \mathrm{L}=1.3 \mathrm{~mm} ; \mathrm{M}=3.7 \mathrm{~cm} ; \mathrm{P}=$ $2.6 \mathrm{~mm}$. A, D, E, G, H - L from Ramos BS 39368; B, C, M - P from Sulit PNH 17083 (sheets 1 \& 2); F from Sulit \& Conklin PNH 17745. DRAWN BY ANDREW BROWN. 
1. Gouania fimbriata Reiss. ex Lauterb. (Lauterbach 1922: 338). Type: Philippines, Luzon, Prov. Albay, 1836, Cuming 973 (lectotype, selected here: W!-image seen [W 0076908], isolectotype: K! [K001293409]).

Gouania domingensis sensu Blanco (1837: 196), non L.

Gouania microcarpa sensu Rolfe (1885: 211), pro parte, non DC.

Gouania microcarpa sensu Vidal (1886: 92), pro parte, non DC.

Gouania domingensis sensu Merr. (Merrill: 1918: 245) non L.

Gouania microcarpa sensu Merr. (Merrill: 1918: 245) non DC.

Gouania javanica sensu Merr. (Merrill: 1923: 525), pro parte, non Miq.

Gouania tiliaefolia sensu Merr. (Merrill: 1923: 526), pro parte, non Lam.

Woody climber with circinnate tendrils, to at least $3 \mathrm{~m}$ long; girth to at least $5 \mathrm{~cm}$. Indumentum lacking on older branches to dense at distal end of branchlets; stem hairs $0.2 \mathrm{~mm}$ long, curved to tortuous, spreading to appressed-antrorse, mostly reddish-ferruginous, some whitish. Branchlets hollow in the centre, slender, subterete, smooth, with flush longitudinal striations. Stipules fugaceous although often persisting to anthesis, densely hairy, slightly asymmetric, lanceolate, acuminate, pinnatisect, 7 (- 9) $\mathrm{mm}$ long, medial undivided portion c. $1.3 \mathrm{~mm}$ wide, divisions narrow, c. $0.2 \mathrm{~mm}$ wide, to $3 \mathrm{~mm}$ long. Leaves: discolorous, dark green adaxially, glossy adaxially when fresh, paler abaxially, blade wide ovate - ovate, $3.0-8.2 \mathrm{~cm}$ long, $2.0-6.0 \mathrm{~cm}$ wide, chartaceous, apex attenuate (acuminate), base rounded to cordate, margins weakly serrate, usually 15 - 20 serrations on either side, margin subentire in proximal $1 / 3$, serrations more densely crowded at leaf apex, margin with one protruding gland at the apex of each serration, glands crowned with hairs, leaf margin often ciliate; primary vein densely hairy abaxially, hairs mostly appressed, antrorse; secondary veins (5-) $6-7$ pairs, densely hairy abaxially, venation eucamptodromous, basal secondary veins reaching margin at c. $60 \%$ of leaf height, angle of divergence from primary vein 30 $40^{\circ}$; outer secondary veins branching off basal secondary veins conspicuous, $4-5$; lamina glabrous adaxially when leaf mature, including along veins; lamina glabrous to sparsely hairy abaxially when leaf mature, densely hairy when immature; domatia usually present in vein axils, a foliaceous appendage or tufts of hairs; petiole subterete, flattening distally, channelled, 8 $21 \mathrm{~mm}$ long, densely hairy, with glands and foliaceous appendages, especially along edges of channel and near junction with leaf blade, similar to appendages found in domatia. Inflorescence of congested cymes arranged along racemiform thyrses, the distal thyrses often arranged in a panicle, thyrses to $25 \mathrm{~cm}$, with c. 6 flowers in each cyme; bracts narrow-lanceolate, acuminate, 4 - $6 \mathrm{~mm}$ long, pinnatifid, densely hairy; cymes mostly pedunculate, peduncles $1-4 \mathrm{~mm}$ long, pedicels to $1.5 \mathrm{~mm}$ long, densely hairy. Flower odour unknown; hypanthium densely hairy adaxially, indumentum often paler than on inflorescence rachis, sepals triangular, c. $1.0 \mathrm{~mm}$ long, greenish-white when fresh, glabrous and keeled adaxially; petals clawed, c. $1.0 \mathrm{~mm}$ long, rugulose adaxially, colour when fresh unknown; stamen filaments flat, subulate, c. $0.7 \mathrm{~mm}$ long, anthers c. $0.2 \mathrm{~mm}$ long, enclosed by petals, nectary disk stellate, glabrous, smooth, diameter excluding lobes c. $1.5 \mathrm{~mm}$, annulus glabrous, raised, tightly sheathing style, disk lobes narrow, tapering, apex often notched, usually appressed to sepal lobe when dry, $0.5-0.7 \mathrm{~mm}$ long ( $2 / 3$ of sepal length); style arms 3, glabrous. Fruit green when fresh, fruit body glabrous to sparsely hairy, more densely near apex, drying darker brown than wings, c. $4.5 \mathrm{~mm}$ high, wings glabrous, c. $7 \mathrm{~mm}$ high, $>1.5 \times$ height of fruit body, distance between highest points of wings $3-5 \mathrm{~mm}$, mericarp width $7-9 \mathrm{~mm}$, fruit body width $2-3 \mathrm{~mm}, 1 / 3$ mericarp width. Seeds $3 \times 2$ $\mathrm{mm}$. obovate, dorsally convex, ventrally concave, shiny brown.

DISTRIBUTION. Philippines: Luzon. Map 1. ADDITIONAL SPECIMENS EXAMINED. PHILIPPINES. LUZON. ABRA: Poblacion Gangal, Municipality of Sallapadan $17^{\circ} 28.0^{\prime} \mathrm{N} 120^{\circ} 49.6^{\prime} \mathrm{E}, 250 \mathrm{~m}, 14$ Nov. 1996, Fuentes $\mathcal{E}^{\circ}$ de la Rosa PPI 38586 (L!); Prov. of Abra, Jan. 1909; Ramos BS 7117 (L!, P!-image seen); BULACAN: Norzagaray, Jan. 1911, Foxworthy BS 122411 (E!); Mt Biak na Bato, San Miguel, $15^{\circ} 7.5^{\prime} \mathrm{N} 121^{\circ} 4.7^{\prime} \mathrm{E}, 12$ Sept. 1994, Garcia et al. PPI 15057 (L!); CAGAYAN: Peñablanca, Quibal along the river $\left[17^{\circ} 43^{\prime} \mathrm{N}\right.$ 121 48'E], 20 Jan. 1994, Reynoso et al. PPI 11785 (BISH, L!); ILOCOS NORTE: Mt Pico de Loro, Brgy, Dampig, Pagudpod $14^{\circ} 12.9^{\prime} \mathrm{N} 120^{\circ} 38.8^{\prime} \mathrm{E}, 450 \mathrm{~m}$, Garcia $\mathcal{E}^{\circ}$ Fernando PPI 25152 (K!, L!-image seen); Nagbasalan [Nagbacalan] [18 $5^{\prime} \mathrm{N} 120^{\circ} 37^{\prime} \mathrm{E}$ ], 2 Feb. 1955, Menor PNH 34153 (K!); LAGUNA: Cavinti, Feb. 1906, Loher 5825 (K!); ibid., 7 Feb. 1906, Loher 5836 (K!); MANILA: Manille, 1857, Barthe s.n. (L!); Novaliches, 1 Feb. 1890, Loher 328 (K!); San Juan del Monte, Oct. 1883, Vidal y Soler 197 (K!); NUEVA VIZCAYA: Carasacas, 3 Feb. 1955, Martin PNH 33505 (L!); PAMPANGA: Arayat, March 1903, Merrill 1425 (K!, L!-image seen); QUEZON: Balara, 26 Jan. 1952, Layosa PNH 15015 (L!); San Francisco del Monte, 8 Dec. 1893, Loher 326 (K!, P!image seen); RIZAL: Bosoboso [14 $38^{\prime} \mathrm{N} 121^{\circ} 14^{\prime} \mathrm{E}$ ], Dec. 1904, Ahern's collector Forestry Bureau 2159 (K!, P!-image seen); ibid., 20 Jan. 1892, Loher 327 (K!, P!image seen); Montalban [Rodriguez], Dec. 1906, Loher 5841 (K!); Antipolo, Jan. 1914, Merrill 250 (K!, P!image seen); ibid., 8 Feb. 1953, Manayon 69 (L!); Rizal, Dec. 1909, Ramos 96 (U!-image seen); ibid., Jan. 1907, 


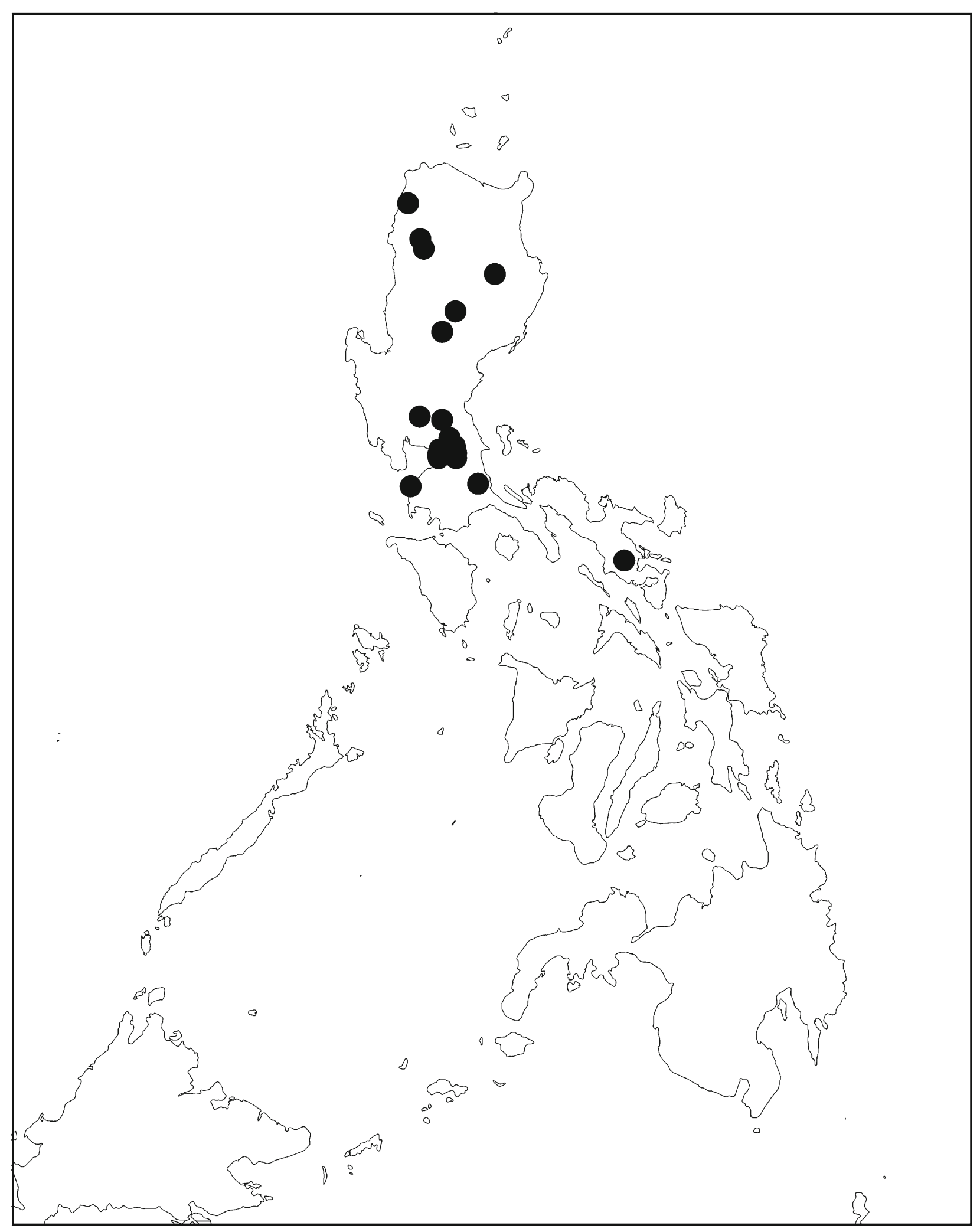

Map 1. Distribution of Gouania fimbriata $(\bullet)$. 
Ramos BS 1749 (K!, WRSL!-image seen); Antipolo, Araneta, 25 Jan. 1953, Viola 34 (L!).

HABITAT. Luzon rain forests; alt. $0-450 \mathrm{~m}$.

CONSERVATION STATUS. Gouania fimbriata was collected in many parts of Luzon, from Albay in the south-east to Ilocos Norte in the north-west, including several collections in the 1990s from various parts of the island (Abra, Bulacan, Cagayan, Ilocos Norte). The species has been observed in less threatened parts of the island, along the Central Cordillera and Southern Sierra Madre. The EOO of $G$. fimbriata is of over $85,000 \mathrm{~km}^{2}$ and it is assessed here as of Least Concern (LC). However, most collections available were made before World War II, including many made near Manila where the species could be severely threatened. Populations could also be threatened in the Central Luzon Plains and Cagayan River Valley, which have experienced extensive clearing for logging and agricultural use (Lamoreux 2001).

PHENOLOGY. Mostly collected in flower from Dec. to Feb., but also Sept. and Oct.; collected in fruit (mature, splitting) from Jan. to March and Oct.

VERNACULAR NAMES. Lituan (Tagalog, fide Viola 34); Sitiran or Fitiran (Tagalog, fide Manayon 69).

NOTES. Gouania fimbriata is recognised by its deeply pinnatifid stipules and bracts and by the stipules often persisting at anthesis on herbarium specimens. The leaf lamina is glabrous to sparsely hairy abaxially when mature and cymes are borne on peduncles $1-4 \mathrm{~mm}$ long. The other known species of the genus found in the Philippines are G. nematostachya, which has a rugose nectar disk with no narrow lobes opposite the sepals, and $G$. longipedunculata, which has abundantly to densely hairy mature leaves and peduncles to $8 \mathrm{~mm}$ long (Table 1).

Like Gouania nematostachya, this species was published by Lauterbach (1922) based on a manuscript name and notes by Reissek with no clear indication of type specimens and has hardly appeared in the taxonomic literature since (see Notes for G. nematostachya).

In his description of Gouania domingensis, Blanco (1837) specified that narrow disk lobes are present opposite the sepal lobes, which rules out that he was referring to $G$. nematostachya. In addition, he wrote that the leaves are somewhat hairy, unlike the densely hairy leaves of $G$. longipedunculata. Blanco observed the plant in Angat on Luzon where G. longipedunculata is not known to occur. It is therefore most likely that G. domingensis sensu Blanco is a synonym of G. fimbriata. Merrill (1918: 245) selected Merrill 250 - a G. fimbriata specimen - as illustrative of Blanco's G. domingensis. Merrill (loc. cit.) also reduced $G$. domingensis sensu Blanco to a synonym of G. microcarpa, a name commonly used to designate Gouania specimens from the Philippines despite being a species restricted to India and Sri Lanka (also see Notes for G. nematostachya).
The lectotype of Gouania fimbriata selected here was collected in Albay according to the specimen's label. However, the collection location may have been Pangasinan according to Merrill (1915: 183).

2. Gouania leptostachya DC. (de Candolle 1825: 40). Type: India, Calcutta, cultivated in Hort. Bot. Calcutta, Oct. 1815, Wallich s.n. (lectotype, selected here: G-DC!image seen [G00476307]).

Naegelia dubia Zoll. \& Moritzi (Moritzi 1846: 20) Type: Indonesia, Java, Jawa Barat, Prov. Bandong [Bandung], bei Tjikoya [Cikuya], March 1843, Zollinger 1183 (lectotype, selected here: P!-image seen [P06788276], isolectotype: A!-image seen [A 00051366]).

Gouania tiliaefolia sensu Roxb. (Roxburgh 1795: 68), non Lam.

Gouania tiliaefolia sensu Blume (1826: 1152), non Lam.

Woody climber with circinnate tendrils, to at least $20 \mathrm{~m}$ long; girth to $15 \mathrm{~cm}$. Indumentum lacking on branchlets except on rachis of racemiform thyrses. Branchlets hollow in the centre, slender, subterete, often flattened distally by collapsing inside hollow section, smooth, with flush longitudinal striations. Stipules soon fugaceous, glabrous except at apex and along margins, asymmetric, upper lobe lanceolate, acuminate, c. $4 \mathrm{~mm}$ long, entire, lower lobe lanceolate, acuminate, diverging at a c. $120^{\circ}$ angle from the upper lobe, c. $1.0 \mathrm{~mm}$ long. Leaves: discolorous, dark green adaxially, paler abaxially, blade (narrow-)ovate, $4.5-10.0 \mathrm{~cm}$ long, $2.5-6.2 \mathrm{~cm}$ wide, chartaceous, shiny when fresh, apex acuminate, base rounded to cordate, margins crenate, up to 30 serrations on either side, all along leaf margin, quite evenly spaced, serrations with glands submarginal, often in a small depression, leaf margin glabrous; primary vein sparsely to abundantly hairy, hairs mostly appressed, antrorse; secondary veins $4-5$ pairs, sparsely to abundantly hairy, venation eucamptodromous, basal secondary veins reaching margin at c. $60 \%$ of leaf height. angle of divergence from primary vein $35-50^{\circ}$; outer secondary veins branching off basal secondary veins often conspicuous, 3 - 5; lamina glabrous to very sparsely hairy adaxially and abaxially; domatia lacking; petiole subterete, channelled, often laterally compressed, 7 $29 \mathrm{~mm}$ long, glabrous except along edges of channel, with glands and foliaceous appendages, especially near junction with leaf blade. Inflorescence of congested cymes arranged along racemiform thyrses, the distal thyrses often arranged in a panicle, thyrses to $35 \mathrm{~cm}$, with c. 5 flowers in each cyme; bracts narrowlanceolate, acuminate, c. $2.5 \mathrm{~mm}$ long, entire, glabrous; cymes sessile, pedicels to $2.5 \mathrm{~mm}$ long, sparsely hairy. Flowers scented; hypanthium adaxially sparsely hairy at base, more densely distally; sepals triangular, 
Table 1. Morphological comparison between species of Gouania in the Philippines.

\begin{tabular}{|c|c|c|c|}
\hline & G. fimbriata & G. longipedunculata & G. nematostachya \\
\hline Stipules & $\begin{array}{l}\text { often persisting to anthesis } \\
\text { pinnatisect } \\
7(-9) \mathrm{mm} \text { long }\end{array}$ & $\begin{array}{l}\text { often persisting to anthesis } \\
\text { pinnatisect } \\
7(-9) \mathrm{mm} \text { long }\end{array}$ & $\begin{array}{l}\text { soon fugaceous } \\
\text { entire } \\
\text { c. } 2.5 \mathrm{~mm} \text { long }\end{array}$ \\
\hline \multicolumn{4}{|l|}{ Leaves } \\
\hline Margin & $\begin{array}{l}\text { weakly serrate, usually } 15-20 \\
\text { serrations on either side } \\
\text { margin subentire in } \\
\text { proximal } 1 / 3 \text {, serrations } \\
\text { more densely crowded } \\
\text { at leaf apex }\end{array}$ & $\begin{array}{l}\text { weakly serrate, usually } \\
15-20 \text { serrations on either side } \\
\text { margin subentire in proximal } \\
1 / 3 \text {, serrations more } \\
\text { densely crowded at leaf apex }\end{array}$ & $\begin{array}{l}\text { finely and densely serrate, } \\
\text { usually } 40-50 \\
\text { serrations on either side } \\
\text { serration spacing } \pm \text { regular along margin }\end{array}$ \\
\hline Domatia & usually present in vein axils & usually present in vein axils & absent \\
\hline Secondary veins & $(5-) 6-7$ pairs & $(5-) 6-7$ pairs & $(4-) 5-6$ pairs \\
\hline $\begin{array}{l}\text { Abaxial surface } \\
\text { Inflorescence }\end{array}$ & glabrous to sparsely hairy & abundantly to densely hairy & sparsely to abundantly hairy \\
\hline Bracts & $\begin{array}{l}4-6 \mathrm{~mm} \text { long } \\
\text { pinnatifid }\end{array}$ & $\begin{array}{l}2-5 \mathrm{~mm} \text { long } \\
\text { entire to pinnatifid }\end{array}$ & $\begin{array}{l}\text { c. } 2.5 \mathrm{~mm} \text { long } \\
\text { entire }\end{array}$ \\
\hline \multicolumn{4}{|l|}{ Flower } \\
\hline Disk surface & smooth & smooth & rugose \\
\hline Disk lobes & $\begin{array}{l}\text { present, narrow, tapering, } \\
\pm^{2} / 3 \text { sepal length }\end{array}$ & $\begin{array}{l}\text { present, narrow, tapering, } \\
\pm^{2} / 3 \text { sepal length }\end{array}$ & absent \\
\hline Peduncle length & up to $4 \mathrm{~mm}$ & up to $8 \mathrm{~mm}$ & undeveloped \\
\hline Pedicel length & up to $1.5 \mathrm{~mm}$ & up to $3 \mathrm{~mm}$ & up to $2 \mathrm{~mm}$ \\
\hline Body height & c. $4.5 \mathrm{~mm}$ & c. $4.5 \mathrm{~mm}$ & c. $5 \mathrm{~mm}$ \\
\hline Wing height & c. $7 \mathrm{~mm}$ & c. $7 \mathrm{~mm}$ & $6-7 \mathrm{~mm}$ \\
\hline Mericarp width & $7-9 \mathrm{~mm}$ & $6-8 \mathrm{~mm}$ & $9-11 \mathrm{~mm}$ \\
\hline Seed size & $3 \times 2 \mathrm{~mm}$ & $2 \times 2.5 \mathrm{~mm}$ & $3 \times 2 \mathrm{~mm}$ \\
\hline
\end{tabular}

c. $1.2 \mathrm{~mm}$ long, often rugulose adaxially, white when fresh, glabrous and keeled abaxially; petals clawed, c. $1.1 \mathrm{~mm}$ long, rugulose adaxially, whitish-cream when fresh; stamen filaments flat, subulate, c. $0.9 \mathrm{~mm}$ long, anthers c. $0.2 \mathrm{~mm}$ long, enclosed by petals, nectary disk stellate, glabrous, often rugulose, diameter excluding lobes c. $1.8 \mathrm{~mm}$, annulus glabrous, barely raised, loose around style, disk lobes narrow, with parallel sides, usually bending away from sepal lobes when dry, apex entire to slightly notched, c. $0.6 \mathrm{~mm}$ long ( $1 / 2$ of sepal length); style arms 3, glabrous, often undeveloped. Fruit green when fresh, glabrous, drying yellowish-brown, fruit body c. $8 \mathrm{~mm}$ high, wings 9 $12 \mathrm{~mm}$ high, c. $1.3 \times$ height of fruit body, distance between highest points of wings c. $7 \mathrm{~mm}$, mericarp width $10-16 \mathrm{~mm}$, fruit body width c. $4 \mathrm{~mm}, 1 / 3$ mericarp width. Seeds $4 \times 4 \mathrm{~mm}$. obovate, dorsally convex, ventrally concave, shiny brown.

DISTRIBUTION. In Sundaland: Malay Peninsula, Sumatra and Java. Also found in the Andaman and Nicobar Islands, Bhutan, China, India, Laos, Myanmar, Nepal, Thailand and Vietnam. Map 2 (Sundaland occurrences only).

ADDITIONAL SPECIMENS EXAMINED. INDONESIA. JAVA. s.a., Blume s.n. (K!); s.a., Horsfield s.n.; s.a., Spanoghe s.n. (K!); s.a., s.c. (K! [K001293563]); JAWA BARAT: Preanger, Bantardawa, Bandjar [Banjar] [7²3' N 108 34'E], 28 Dec. 1910, Backer 1911 (L!); Res. Batavia, Pondok Salam (bij Poerwakarta [Purwakarta]) [6 $37^{\circ} \mathrm{N}$ $107^{\circ} 30 ' \mathrm{E}$ ], 300 m, 28 July 1920, Bakhuizen van den Brink Sr 4873 (K!, L!-image seen). SUMATRA. RIAU: c. 50 m, 4 Aug. 1988, Project Soma EM17 (E!); SUMATERA UTARA: Medan Southward along the Petani, $30 \mathrm{~m}, 25$ June 1928, Lörzing 13270 (K!, L!-image seen); MALAYSIA. PENINSULAR MALAYSIA. JOHOR: Pulau Pemanggil, Latiff E⿱ Zainudin 1133 (UKMB n.v.); PAHANG: Raub track, May 1903, Machado 11604 (K!); PERAK: Larut [Taiping], $200 \mathrm{ft}$ [50 m], Aug. 1884, King's collector 6420 (E!-image seen); s.a., Scortechini 1158 (L!, P!image seen); s.a. Scortechini s.n. (K!); Kampong Kota [4²8'N 10047'E], July 1889, Wray Jr 3324 (P!-image seen); ibid., Feb. 1889, Wray Jr 3346 (L!); MYANMAR. TANINTHARYI REGION: Kyakaik [10 $\left.41^{\circ} \mathrm{N} 98^{\circ} 27^{\prime} \mathrm{E}\right], 28$ Sept. 1932, Parkinson 15131 (NY!-image seen); THAILAND. CHUMPHON: Chumpawn, c. 50 m, 27 Jan. 1927, Kerr 11654 (K!, L!-image seen); Sawee, Khaokhai, Road from Sawee to La-Un, 200 m, 26 Dec. 2006, Pooma et al. 6685 (E!, GH!, L!-image seen); RANONG: Ban Na, Kapur [Kapoe], c. 50 m, 8 Dec. 1976, Santisuk 789 (K!); Ranawng, 3 Jan. 1929, Kerr 16503 (K!); SATUN: Kuan Po [Kuan Pho] [6 $\left.6^{\circ} 45^{\prime} \mathrm{N} 100^{\circ} 1 ' \mathrm{E}\right]$, c. $20 \mathrm{~m}$, Jan. 1928, Kerr 13830 (K!, L!-image seen); La-Ngu, c. 5 m, 8 Jan. 1928, Kerr 13944 (K!, L!-image seen); Khaun Kradon [Khuan Kalong], 7 Dec. 1986, Niyomdham 1292 (L!); SONGKHLA: Kopah Ban Krap, 12 Dec. 1917, Haniff $\mathcal{E}$ Nur 2911 (K!); SURAT THANI: Phano, Khao Sok. Km 99 trail from the road towards the reservoir, $8^{\circ} 54^{\prime} 54^{\prime \prime} \mathrm{N} 98^{\circ} 36^{\prime} 11^{\prime \prime E}, 200 \mathrm{~m}, 2006$, Middleton et al. 4019 (E!-image seen, L!-image seen); 


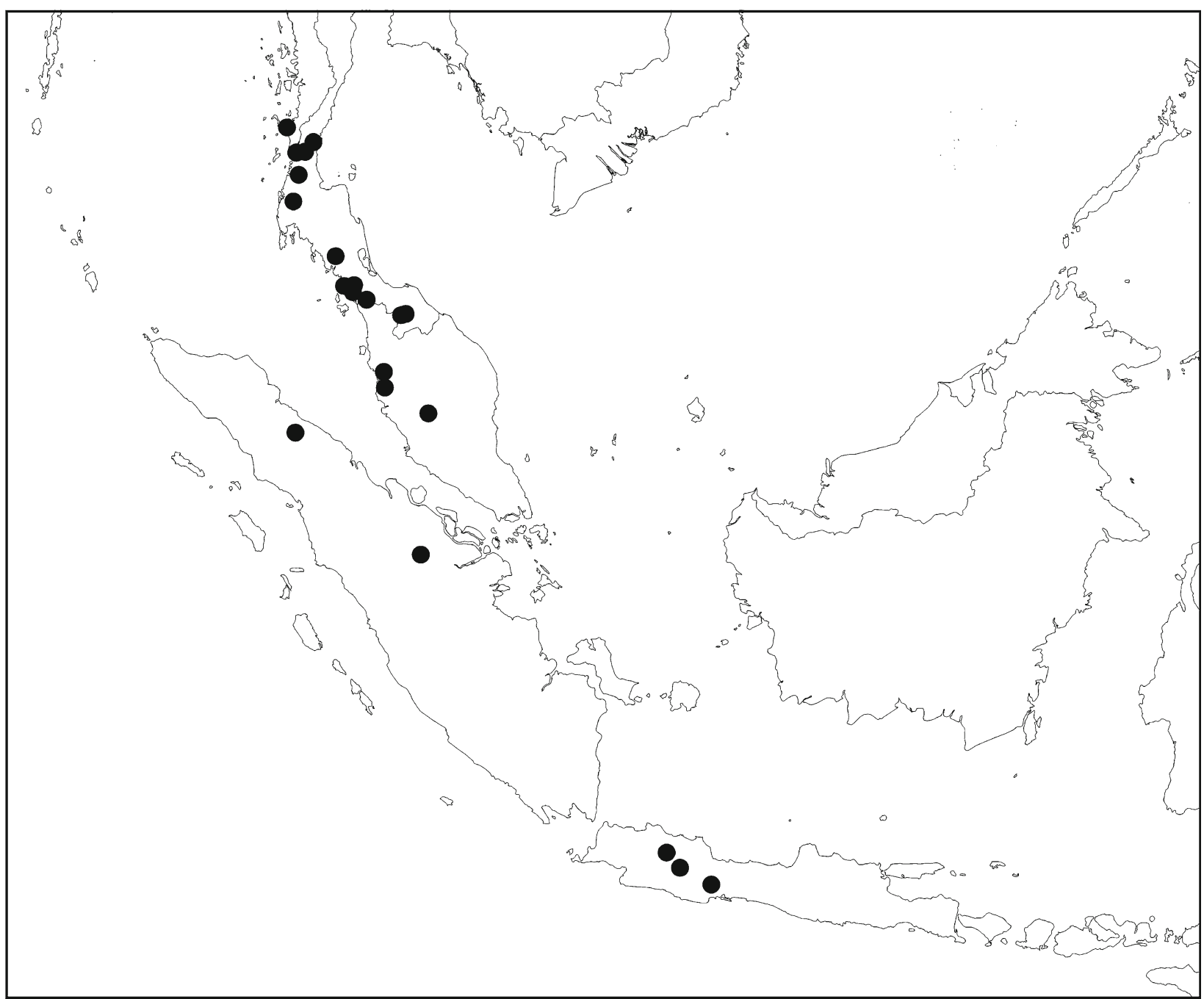

Map 2. Distribution of Gouania leptostachya (•) in Sundaland.

TRANG: Mueang Trang, 10 m, Oct. 1915, Vanpruk 766 (K!); YALA: Than To waterfall, $45 \mathrm{~km} \mathrm{~S}$ of Yala and surroundings, $6^{\circ} 12^{\prime} \mathrm{N} 101^{\circ} 10^{\prime} \mathrm{E}, 100-200 \mathrm{~m}, 27$ Nov. 1990, Larsen et al. 41762 (P!-image seen); Ba Nang Sata [Bannang Sata], 6 Dec. 1986, Niyomdahm 1292 (E!-image seen, K!); Bannang Sata, 23 Nov. 1961, Suwanakoset 1714 (K!, L!).

HABITAT. Tropical moist broadleaf forests, specifically Tenasserim-South Thailand semi-evergreen rain forests, Peninsular Malaysian lowland rain forests, Sumatran lowland rain forests and Western Java lowland rain forests; alt. $0-200 \mathrm{~m}$. Habitat for regions outside Sundaland not indicated here.

CONSERVATION STATUS. With a broad distribution from Uttar Pradesh and Nepal, across Assam and IndoChina to Java, Gouania leptostachya is not threatened. In Sundaland, its EOO is over $450,000 \mathrm{~km}^{2}$ and is assessed here as of Least Concern (LC). However, only two Sundaland specimens available for study were collected since 1990. Both were collected in Thailand. The status of the species in Malaysia and Indonesia is very uncertain. No recent records for either country were found in GBIF (2018).

PHENOLOGY. Collected in flower in Jan. - March, Aug., Oct and Nov.; collected in fruit (mature, splitting) in Jan., May - July, Sept. and Dec.

VERNACULAR NAMES. Am dap tai (Chumphon and Ranong, fide Kerr 11654 and Kerr 16503); Areuj sahagi (Sunda, Heyne 1917); Areuj s r rp (Sunda, ibid.); Aroijsirareb (Sundanese, Filet 1876); Garangan (Java, ibid.); Phi-khum (Myanmar, Kress et al. 2003); Saw-sam-daw-ku (Tanintharyi, fide Parkinson 15131); S r r p (Java, Heyne 1917); Si Chan (Satun, fide Kerr 13830); Sowagi-aroij (Sundanese, Filet 1876); Tayaw-nyo-new (Myanmar, Kress et al. 2003).

USES. Finely crushed roots, stems and leaves were used externally against headaches and as a treatment for scabies; shampoo made from the bark and applied to the scalp was used to kill parasites (Heyne 1922).

NOTES. Gouania leptostachya is the only species in Sundaland to have stipules with a basal lobule 
pointing sideways, glabrous bracts, $4-5$ pairs of secondary veins, marginal glands sunken inside margin serrations, a fruit body c. $8 \mathrm{~mm}$ high and that has the same colour as the wings; mericarps $10-16 \mathrm{~mm}$ wide and seeds $4 \times 4 \mathrm{~mm}$. All other species have unlobed stipules (entire to pinnatifid), hairy bracts, usually at least 5 pairs of secondary veins, protruding marginal glands, a fruit body to $5 \mathrm{~mm}$ high and that is usually darker than the wings, mericarps to $12 \mathrm{~mm}$ wide and seeds to $3 \times 2.5 \mathrm{~mm}$ (Table 2 ).

Gouania retinaria DC. is listed as a possible synonym of $G$. leptostachya by Suessenguth (1953). According to Buerki et al. (2011), G. retinaria is instead a synonym of G. scandens (Gaertn.) R.B.Drumm., which occurs in Mauritius, Réunion and Madagascar. Gouania leptostachya material from Sundaland was identified as G. tiliaefolia [G. tiliifolia Lam.] by Blume (1826), which is also synonym of $G$. scandens according to Buerki et al. (loc. cit.).

A. P. de Candolle cited material from the botanical garden of Calcutta in his protologue of Gouania leptostachya. The sheets found in G-DC include a specimen from Hort. Bot. Calcutt. designated here as the lectotype. Additional material of G. leptostachya from the botanical garden of Calcutta listed in the Wallich Catalogue (Catalogue no 4270.E) is present in herbaria (e.g. G!-image seen [G00378049], K-W! [K001038588], E!-image seen [E00777941]). Because De Candolle received material from Calcutta before Wallich started sorting the East India Company specimens, it is uncertain as to whether these specimens are duplicates of the type and they are not listed here as isolectotypes. The lectotype for Nagelia dubia is selected here at $\mathrm{P}$ where Java collections by Zollinger and received by Moritzi are held according to Stafleu \& Cowan (1981: 589).

Several authors have described Gouania leptostachya flowers as polygamous (Hooker 1862; Kurz 1877; Brandis 1906; Gamble 1935; Chen \& Schirarend 2007). All examined flowers were perfect, although style branches were undeveloped in some flowers (D. Cahen pers. obs.). Whether the flowers were functionally male by abortion could not be conclusively observed in herbarium specimens.

3. Gouania longipedunculata Cahen, Stenn E Utteridge sp. nov. Type: Philippines, Mindoro, Mt Calavite [13⒉ $28^{\prime} \mathrm{N} 120^{\circ} 23^{\prime} \mathrm{E}$ ], April 1921, Ramos BS 39368 (holotype K! [K001293410]).

http://www.ipni.org/urn:lsid:ipni.org:names:77204803-1

Woody climber with circinnate tendrils, to at least $2 \mathrm{~m}$ long; girth unknown. Indumentum lacking on older branches to dense at distal end of branchlets; stem hairs $0.2 \mathrm{~mm}$ long, curved to tortuous, spreading to appressed-antrorse, mostly reddish-ferruginous, some whitish. Branchlets hollow in the centre, slender, subterete, smooth, with flush longitudinal striations. Stipules soon fugaceous, densely hairy, slightly asymmetric, lanceolate, acuminate, c. $1.5 \mathrm{~mm}$ wide, 7 (-9) $\mathrm{mm}$ long, pinnatisect, divisions narrow, c. $0.2 \mathrm{~mm}$ wide, c. $2 \mathrm{~mm}$ long. Leaves: discolorous, dark green adaxially, paler abaxially, blade wide ovate (-ovate), $3.2-9.5 \mathrm{~cm}$ long, $2.2-7.4 \mathrm{~cm}$ wide, chartaceous, apex attenuate, base rounded to cordate, margins weakly serrate, usually 15 - 20 serrations on either side, margin subentire in proximal $1 / 3$, serrations gradually getting closer to each other towards leaf apex, margin with one protruding gland at the apex of each serration, glands crowned with hairs, leaf margin often ciliate; primary and secondary veins glabrous to densely hairy on primary and secondary veins adaxially, abundantly to densely hairy abaxially, hairs mostly appressed, antrorse; secondary veins (5-) $6-7$ (-8) pairs, venation eucamptodromous, basal secondary veins reaching margin at c. $60 \%$ of leaf height, angle of divergence from primary vein $30-40^{\circ}$; outer secondary veins branching off basal secondary veins conspicuous, 4 - 5; lamina sparsely to abundantly hairy adaxially, sparsely to densely hairy abaxially; domatia usually present in vein axils, a foliaceous appendage or tufts of hairs; petiole subterete, flattening distally, channelled, 8 - $21 \mathrm{~mm}$ long, densely hairy, with glands and foliaceous appendages, especially along edges of channel and near junction with leaf blade, similar to appendages found in domatia. Inflorescence of congested cymes arranged along racemiform thyrses, the distal thyrses often arranged in a panicle, thyrses to $30 \mathrm{~cm}$, with c. 6 flowers in each cyme; bracts lanceolate, acuminate, $2-5 \mathrm{~mm}$ long, entire to pinnatifid, densely hairy; cymes pedunculate, peduncles $1-8 \mathrm{~mm}$ long, pedicels to $3 \mathrm{~mm}$ long, densely hairy. Flower odour unknown; hypanthium densely hairy adaxially, indumentum usually same colour as on inflorescence rachis, sometimes paler, sepals triangular, c. $1.0 \mathrm{~mm}$ long, white when fresh, glabrous and keeled adaxially; petals clawed, c. $1.0 \mathrm{~mm}$ long, rugulose adaxially, colour when fresh unknown; stamen filaments flat, subulate, c. $0.7 \mathrm{~mm}$ long, anthers c. $0.2 \mathrm{~mm}$ long, enclosed by petals, nectary disk stellate, glabrous, smooth, diameter excluding lobes c. $1.5 \mathrm{~mm}$, annulus glabrous, raised, tightly sheathing style, disk lobes narrow, tapering, apex often notched, usually appressed to sepal lobe when dry, $0.5-0.7 \mathrm{~mm}$ long $(2 / 3$ of sepal length); style arms 3, glabrous. Fruit green when fresh, fruit body glabrous to sparsely hairy, more densely near apex, drying darker brown than wings, c. $4.5 \mathrm{~mm}$ high, wings glabrous, c. $7 \mathrm{~mm}$ high, $>1.5 \times$ height of fruit body, distance between highest points of wings $3-4 \mathrm{~mm}$, mericarp width $6-8 \mathrm{~mm}$, fruit body width $2-3 \mathrm{~mm}$, c. ${ }^{1} / 3$ mericarp width. Seeds 3 
Table 2. Morphological comparison between species of Gouania in Sundaland.

\begin{tabular}{|c|c|c|c|}
\hline & G. leptostachya & G. nematostachya & G. obtusifolia \\
\hline Stipules & $\begin{array}{l}\text { lobed } \\
\text { upper lobe entire } \\
\text { c. } 4 \mathrm{~mm} \text { long }\end{array}$ & $\begin{array}{l}\text { unlobed } \\
\text { entire } \\
\text { c. } 2.5 \mathrm{~mm} \text { long }\end{array}$ & $\begin{array}{l}\text { unlobed } \\
\text { entire to pinnatifid } \\
\text { c. } 6 \mathrm{~mm} \text { long }\end{array}$ \\
\hline \multicolumn{4}{|l|}{ Leaves } \\
\hline Apex & acuminate & acuminate & rounded to acute \\
\hline Margin & $\begin{array}{l}\text { crenate, up to } 30 \text { serrations } \\
\text { on either side } \\
\text { glands sunken }\end{array}$ & $\begin{array}{l}\text { densely serrate, } 40-50 \\
\text { serrations on either side } \\
\text { glands protruding }\end{array}$ & $\begin{array}{l}\text { crenate-serrate, c. } 15-20 \\
\text { serrations on either side } \\
\text { glands protruding }\end{array}$ \\
\hline Domatia & absent & absent & present in vein axils \\
\hline Secondary veins & $4-5$ pairs & (4-) 5 pairs & $5-6(-7)$ pairs \\
\hline Surface (abaxial) & glabrous & hairy & hairy \\
\hline \multicolumn{4}{|l|}{ Inflorescence } \\
\hline Thyrse length & up to $35 \mathrm{~cm}$ & up to $35 \mathrm{~cm}$ & up to $25 \mathrm{~cm}$ \\
\hline Bracts & $\begin{array}{l}\text { c. } 2.5 \mathrm{~mm} \text { long } \\
\text { entire }\end{array}$ & $\begin{array}{l}\text { c. } 2.5 \mathrm{~mm} \text { long } \\
\text { entire }\end{array}$ & $\begin{array}{l}\text { c. } 4 \mathrm{~mm} \text { long } \\
\text { entire to pinnatifid }\end{array}$ \\
\hline & glabrous & densely hairy & densely hairy \\
\hline \multicolumn{4}{|l|}{ Flower } \\
\hline Disk diameter & c. $1.8 \mathrm{~mm}$ & c. $1.6 \mathrm{~mm}$ & c. $1.3 \mathrm{~mm}$ \\
\hline Disk surface & smooth to rugulose & rugose & smooth \\
\hline Disk lobes & $\begin{array}{l}\text { with parallel sides } \\
1 / 2 \text { sepal length } \\
\text { usually bending away from sepals }\end{array}$ & absent & $\begin{array}{l}\text { tapering } \\
\text { 3/4 sepal length } \\
\text { usually appressed to sepals }\end{array}$ \\
\hline Disk annulus & $\begin{array}{l}\text { barely raised } \\
\quad \text { loosely sheathing style }\end{array}$ & $\begin{array}{l}\text { barely raised } \\
\quad \text { loosely sheathing style }\end{array}$ & $\begin{array}{l}\text { raised } \\
\text { tightly sheathing style }\end{array}$ \\
\hline \multicolumn{4}{|r|}{ 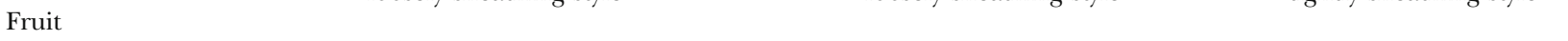 } \\
\hline Pedicel & $\begin{array}{l}\text { to } 2.5 \mathrm{~mm} \text { long } \\
\text { sparsely hairy }\end{array}$ & $\begin{array}{l}\text { to } 2 \mathrm{~mm} \text { long } \\
\text { densely hairy }\end{array}$ & $\begin{array}{l}\text { to } 1 \mathrm{~mm} \text { long } \\
\text { densely hairy }\end{array}$ \\
\hline Body & $\begin{array}{l}\text { c. } 8 \mathrm{~mm} \text { high } \\
\text { same colour as wings } \\
\text { glabrous }\end{array}$ & $\begin{array}{l}\text { c. } 5 \mathrm{~mm} \text { high } \\
\text { darker than wings } \\
\text { glabrous to sparsely hairy }\end{array}$ & $\begin{array}{l}\text { c. } 4 \text { mm high } \\
\text { darker than wings } \\
\text { sparsely hairy }\end{array}$ \\
\hline Wing height & $9-12 \mathrm{~mm}$ & $6-7 \mathrm{~mm}$ & $7-10 \mathrm{~mm}$ \\
\hline Mericarp width & $10-16 \mathrm{~mm}$ & $9-11 \mathrm{~mm}$ & $9-12 \mathrm{~mm}$ \\
\hline Seed size & $4 \times 4 \mathrm{~mm}$ & $3 \times 2 \mathrm{~mm}$ & $2 \times 2 \mathrm{~mm}$ \\
\hline
\end{tabular}

$\times 2.5 \mathrm{~mm}$. obovate, dorsally convex, ventrally concave, shiny brown. Fig. 2.

RECOGNITION. Most like Gouania fimbriata in having narrow disk lobes opposite the sepals, deeply divided stipules often persistent to anthesis and pedunculate cymes, but differs by its abundantly to densely hairy leaves and longer peduncles to $8 \mathrm{~mm}$ long.

DISTRIBUtION. Philippines: Mindanao, Mindoro, Negros and Visayas. Map 3.

ADDITIONAL SPECIMENS EXAMINED. PHILIPPINNES. MINDANAO: Bukidnon, Musuan [7 $\left.52^{\circ} \mathrm{N} 125^{\circ} 4^{\prime} \mathrm{E}\right], 31$ Dec. 1952, Cid 60 (L!); Davao, Todaya (Mt Apo), July 1909, Elmer 11106 (E!-image seen, K!, L!-image seen); Zamboanga, 10 Feb. 1904, Hallier 4625 (L!); MINDORO: ["Mindanao" written on specimen label, see Notes below], s.a., Cuming 1623 (K!, W!-image seen); Abra de Ilog, Jan. 1951, Sulit PNH 13819 (L!); Mt Yagaw (Southern Slope) [12 $\left.33^{\prime} \mathrm{N} 121^{\circ} 20 ' \mathrm{E}\right]$, May June 1953, Sulit E Conklin PNH 17745 (K!); Bo. Manaul, Mansalay, Dec. 1952, Sulit PNH 17083 (K-2 sheets!); NEGROS: Province de Negros Oriental, Dumaguete (Cuernos Mts.) [ $\left.9^{\circ} 18^{\prime} \mathrm{N} 123^{\circ} 17^{\prime} \mathrm{E}\right]$,
June 1908, Elmer 10301 (E!-image seen, K!, L!-image seen); VISAYAS: Cebu, Panilipan, Catmon, $10^{\circ} 44.0^{\prime} \mathrm{N}$ $124^{\circ} 00.8^{\prime} \mathrm{E}, 670 \mathrm{~m}, 12$ June 1997, Gaerlan E Reynoso PPI 20316 (K!, L!-image seen).

HABITAT. Greater Negros-Panay rain forests, Mindanao-Eastern Visayas rain forests, Mindoro rain forests; alt. to at least $670 \mathrm{~m}$.

CONSERVATION STATUS. Gouania longipedunculata was collected on several islands of the Philippines and has an EOO of over $185,000 \mathrm{~km}^{2}$. It is assessed here as of Least Concern (LC), however, except for Gaerlan $\mathcal{E}^{\circ}$ Reynoso PPI 20316 collected in Cebu in 1997, all available specimens were found before the 1960s and may be Near Threatened especially as much of the forest of Mindanao (Morrison 2001b), Negros and Visayas (Morrison 2001a) has been cleared, and Mindoro is one of the most severely deforested islands of the Philippines (Morrison 2001c). However, some collections are from protected areas: Elmer 11106 was collected near Mt Apo, which is currently within a Natural Park (IUCN Category II), but over a century ago. Similarly, Hallier 4625 was collected in Zamboanga, where there currently is a protected area (Pasonanca Natural Park, IUCN Category II), but in 1904. 


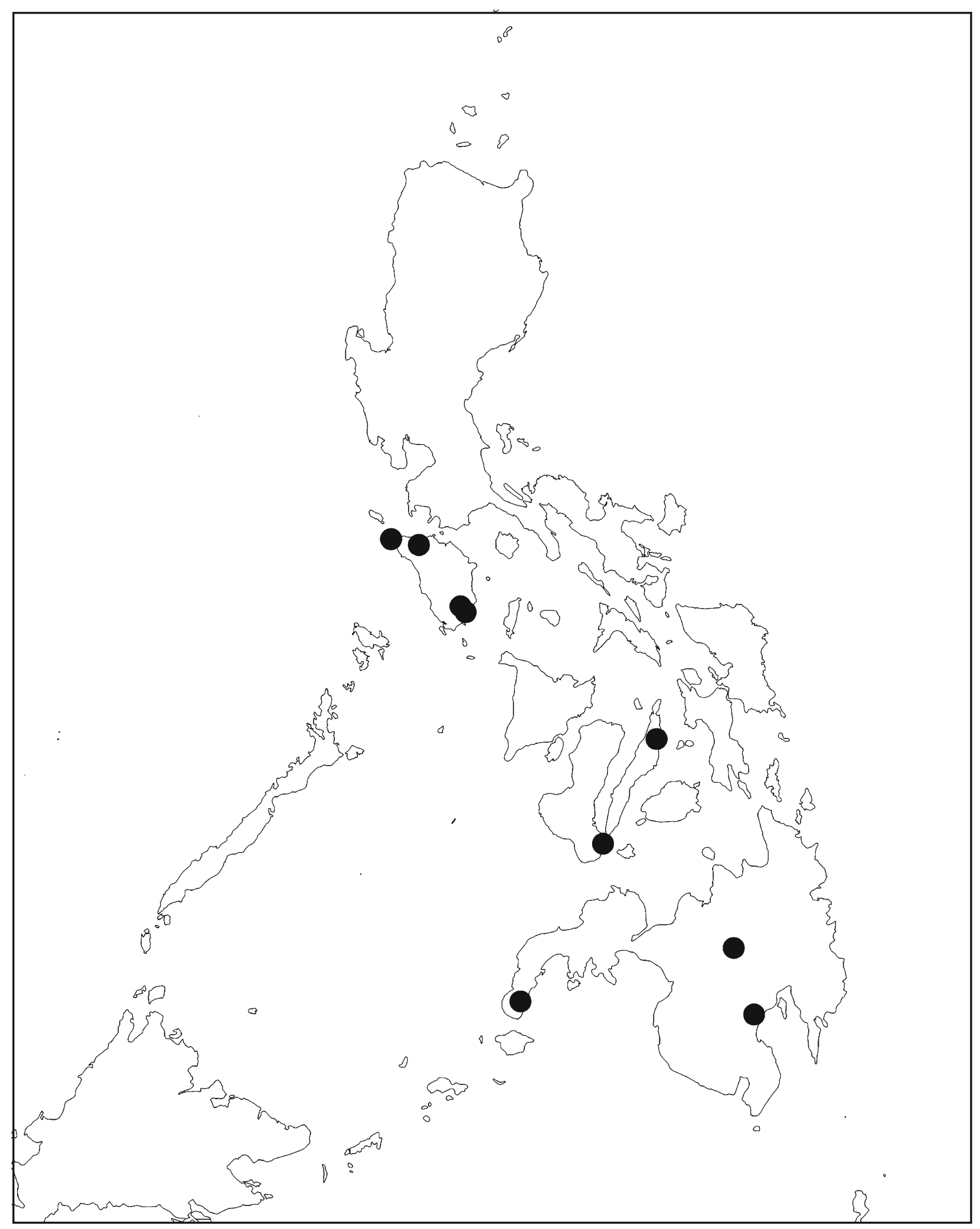

Map 3.. Distribution of Gouania longipedunculata $(\bullet)$. 
PHENOLOGY. Collected in flower in April - July and Dec; collected in fruit (mature, splitting) in Dec. - Feb.

ETYMOLOGY. The specific epithet refers to the peduncles to $8 \mathrm{~mm}$ long, which are the longest of any known Gouania species of Malesia.

NOTES. Gouania longipedunculata is unique in the genus with the following combination of characters: peduncles to $8 \mathrm{~mm}$ long, flower disks with five narrow lobes opposite the sepals and leaves abundantly to very densely hairy abaxially when mature.

All specimens of this species were collected outside of Luzon, in various islands and habitats. There is significant variability in how deeply the bracts are divided and how long the peduncles are. This contrasts with the more morphologically consistent Luzonian Gouania fimbriata. All the specimens examined did however share the character of abundantly to densely hairy mature leaves and peduncles mostly longer than the maximum of $4 \mathrm{~mm}$ for $G$. fimbriata (Table 1). This suggests that $G$. longipedunculata could form a group distinct from $G$. fimbriata but possibly comprising of morphological subsets.

Cuming 1623 is filed as Gouania syringaefolia at W, an unpublished name presumably used by Reissek for this material, although Lauterbach (1922) did not mention such a species. The label on the herbarium specimen at $\mathrm{K}$ indicates that the specimen was collected in Mindanao, but it would have been collected in Mindoro according Merrill (1915: 183).

Specimens of Gouania longipedunculata were originally identified as $G$. microcarpa less often than specimens of G. fimbriata and G. nematostachya. Instead, they were more often identified as $G$. tiliaefolia $[=G$. tiliifolia Lam.], a species restricted to islands of the Western Indian Ocean (see G. leptostachya notes).

4. Gouania nematostachya Reiss. ex Lauterb. (Lauterbach 1922: 339). Type: Philippines, Luzon, Batangas, 1837, Cuming 1578 (lectotype, selected here: W!-image seen [W 0076905], isolectotypes: K! [K001293408], L!-image seen [L.2331975], P!-images seen [P06788291 \& P06788292], WRSL!-image seen).

Gouania microcarpa DC. var. subglabra Elmer (1915: 2801) synon. nov. Type: Philippines, Mindanao, District of Davao, Todaya (Mt Apo) $\left[6^{\circ} 58^{\prime} \mathrm{N}\right.$ $125^{\circ} 21$ 'E], $3750 \mathrm{ft}(1150 \mathrm{~m})$, Aug. 1909, Elmer 11308 (lectotype, selected here: A!-image seen [00051343], isolectotypes: E!-image seen [E 00718589], K!, L!-image seen [L 0484850], NY!image seen [233278], US!-image seen [00094524]).

Gouania microcarpa sensu Rolfe (1885: 211), pro parte, non DC.

Gouania microcarpa sensu Vidal (1886: 92), pro parte, non DC.

Gouania microcarpa sensu Beaman \& C.E.Anderson (2004), non DC.
Gouania javanica sensu Merr. (Merrill: 1923: 525), pro parte, non Miq.

Gouania tiliaefolia sensu Merr. (Merrill: 1923: 526), pro parte, non Lam.

Woody climber with circinnate tendrils, to $30 \mathrm{~m}$ long; girth to at least $6 \mathrm{~cm}$. Indumentum lacking on older branches to dense at distal end of branchlets; stem hairs $0.2 \mathrm{~mm}$ long, curved to tortuous, appressed to spreading, cream to ferruginous. Branchlets hollow in the centre, slender, subterete, smooth, with flat longitudinal striations. Stipules soon fugaceous, unlobed, entire, narrowly triangular, c. $2.5 \mathrm{~mm}$ long, densely hairy. Leaves: discolorous, dark green adaxially, paler abaxially, blade narrow ovate - ovate, $4.0-8.5 \mathrm{~cm}$ long, $2.0-4.9 \mathrm{~cm}$ wide, chartaceous, apex acuminate, base obtuse to cordate, cuneate to rounded in distal leaves, margins densely, finely serrate, serration spacing regular, usually 40 - 50 serrations on either side, all along leaf margin, with one protruding gland at the apex of each serration, glands crowned with hairs, leaf margin often ciliate; primary vein densely hairy abaxially, hairs mostly appressed, antrorse; secondary veins (4-) $5-6$ pairs, densely hairy abaxially, venation eucamptodromous, basal secondary veins reaching margin at c. $60 \%$ of leaf height, angle of divergence from primary vein $30-$ $50^{\circ}$; outer secondary veins branching off basal secondary veins conspicuous, (3-) 4 (- 5); lamina sparsely hairy adaxially, more densely along primary and secondary veins; indumentum sparse to abundant abaxially; domatia lacking; petiole subterete, flattening distally, channelled, $7-24 \mathrm{~mm}$ long, abundant to densely hairy, with glands and foliaceous appendages, especially along edges of channel and near junction with leaf blade. Inflorescence of congested cymes arranged along racemiform thyrses, the distal thyrses often arranged in a panicle, thyrses to $35 \mathrm{~cm}$, with c. 5 flowers in each cyme; bracts narrow-lanceolate, acuminate, c. $2.5 \mathrm{~mm}$ long, entire, densely hairy; cymes sessile, pedicels to $2 \mathrm{~mm}$ long, densely hairy. Flowers scent unknown; hypanthium densely hairy adaxially, sepals triangular, c. $1.0 \mathrm{~mm}$ long, greenish-white when fresh, glabrous and keeled adaxially; petals clawed, c. $1.0 \mathrm{~mm}$ long, smooth adaxially, whitish when fresh; stamen filaments flat, subulate, c. $0.9 \mathrm{~mm}$ long, anthers c. $0.2 \mathrm{~mm}$ long, enclosed by petals, nectar disk 5-angled, glabrous, rugose, diameter c. $1.6 \mathrm{~mm}$, forming a pentagon in outline except notches where petals are inserted to hypanthium, sides truncate to emarginate, annulus glabrous, slightly raised, loosely sheathing style; style arms 3, glabrous. Fruit green when fresh, fruit body glabrous to sparsely hairy, more densely near apex, drying darker brown than wings, c. $5 \mathrm{~mm}$ high, wings glabrous, $6-7 \mathrm{~mm}$ high, c. $1.2 \times$ height of fruit body, distance between highest points of wings c. $7 \mathrm{~mm}$, mericarp width $9-11 \mathrm{~mm}$, fruit body width c. $3 \mathrm{~mm}, 1 / 3$ mericarp 
width. Seeds c. $3 \times 2 \mathrm{~mm}$, elliptic-obovate, dorsally convex, ventrally concave, shiny brown.

DISTRIBUTION. Indonesia: Borneo and Sulawesi; Malaysia: Sabah; Philippines: Luzon, Mindanao, Polillo and Samar. Map 4.

ADDITIONAL SPECIMENS EXAMINED. INDONESIA. BORNEO. SOUTH KALIMANTAN: Doesoen [Barito R.], 1836 [according to van Steenis-Kruseman 2017], Korthals s.n. (L- 4 sheets!), NORTH KALIMANTAN: B. S. Toelit [Bukit Sungai Tulit], Sept. 1912, Amdjah 667 (L!); SULAWESI. CENTRAL SULAWESI: Sopu valley c. $80 \mathrm{~km}$ SSE of Palu, $1^{\circ} 16^{\prime} \mathrm{S} 120^{\circ} 16^{\prime} \mathrm{E}, 1000 \mathrm{~m}, 3$ May 1979, de Vogel et al. 5184 (K!, L!-image seen); ibid., $1^{\circ} 16^{\prime} \mathrm{S} 120^{\circ} 18^{\prime} \mathrm{E}, 1000$ m, 26 May 1979, de Vogel et al.5557 (K-2 sheets!, L!image seen); NORTH SULAWESI: $220 \mathrm{~km}$ W of Manado, $\mathrm{km} 50$ inland from Pangi on Sungai Ilanga, $0^{\circ} 41^{\prime} \mathrm{N}$ $123^{\circ} 40$ 'E, 500 m, 3 March 1990, Burley et al. 3622 (GH!, K!); Minahasa, 50 m, 25 Feb. 1895, Koorders 169433 (L!); Prov. Minahassa, 500 m, 25 Jan. 1895, Koorders 18451 (L!); Bolaang Mongondow: Gunung Ambang Nature Reserve, Danau Mooat area, $0^{\circ} 44^{\prime} \mathrm{N} 124^{\circ} 27^{\prime} \mathrm{E}$, 1000 m, 14 April 1985, de Vogel E Vermeulen 7170 (K!, L!-image seen); Dumoga - Bone proposed N.P.

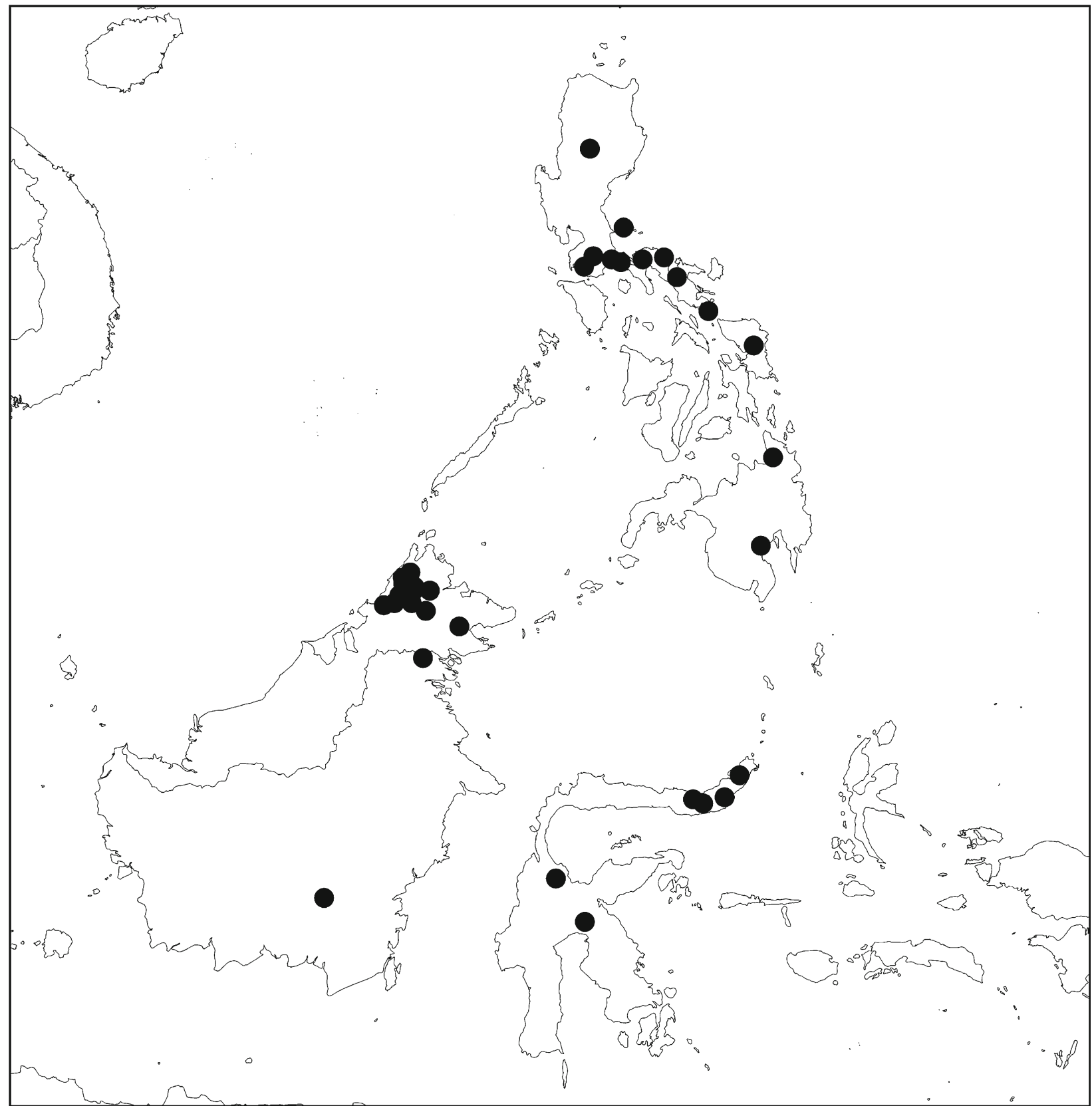

Map 4. Distribution of Gouania nematostachya (•). 
Doloduo, Tumokang, Lama [0 $\left.35^{\prime} \mathrm{N} 123^{\circ} 55^{\prime} \mathrm{E}\right], 270 \mathrm{~m}$, 20 Sept. 1984, Whitmore E Sidiyasa TCW 3467 (K!, L!image seen); SOUTH SULAWESI: Kab. Luwu [East Luwu Regency], Ds. Teromu [Teromu Desa], Faruhumpenai, 350 m, 19 Feb. 1986, Wardi 79 (L!); MALAYSIA. MALAYSIAN BORNEO. SABAH. Upper Kinabalu, $6000-13500 \mathrm{ft}[1800-4100 \mathrm{~m}], 1$ Sept. 1939, Clemens 26263 (K!, L!-image seen); BELURAN: Sg. Ansuan, Meliau, 100 m, 13 Aug. 2003, Diwol Ẽ Markus SAN 136538 (K!, L!-image seen); KENINGAU: Crocker range mil. 16, Kimanis road, 18 Aug. 1986, Krispinus SAN 113804 (K!, L!-image seen); Miles 84.5 on path from Tenom to Ranau (200 miles SW of Kerakot village), 2,400 ft [750 m], 27 Aug. 1954, Wood E WyattSmith SAN A4435 (GH!, L!); KOTA BELUD: Kampung Kiau Nuluh [6 ${ }^{\circ} 1$ 'N 116 $\left.29 ' \mathrm{E}\right], 6$ Aug. 1993, Duaneh 429 (K!); Kampung Melangkap Tomis, Kapazaan 1 km dari Melangkap Tomis [6 $\left.{ }^{\circ} 10^{\prime} 116^{\circ} 29 ' \mathrm{E}\right], 10$ July 1995, Lugas 757 (K!); ibid., 10 Aug. 1995, Lugas 786 (K!); KOTA MARUDU: Kampung Kias [6 $\left.6^{\circ} 18^{\prime} \mathrm{N} 116^{\circ} 40^{\prime} \mathrm{E}\right], 21$ June 1994, Bakia 217 (K!); LAHAD DATU: Segama Piton, 280 ft [100 m], 6 Aug. 1961, Chai SAN 25993 (K!); RANAU: Kinorotuan [Kampung Kinaratuan] [5 $58^{\prime} \mathrm{N}$ 116 $44^{\prime} \mathrm{E}$ ], 11 Aug. 1987, Amin et al. SAN 119834 (E!, K!, L!-image seen); Ulu Sungai Liwagu [5 $32^{\prime} \mathrm{N}$ 116 ${ }^{\circ}$ 'E], 13 Aug. 1987, Amin $\mathcal{E}^{\circ}$ Francis SAN 120922 (K!, L!-image seen); Randagong [5 ${ }^{\circ} 52^{\prime} \mathrm{N} 116^{\circ} 34^{\prime} \mathrm{E}$ ], 14 July 1988, Amin E् Francis SAN 121537 (K!); Batu 7, Jln. Mamut, 8 Sept. 1988, Amin E Suin SAN 123312 (K!, L!-image seen); Tambunan Road, $2 \mathrm{~km} \mathrm{E} \mathrm{of}$ Ranau, 5 $50^{\prime} \mathrm{N} 116^{\circ} 34^{\prime} \mathrm{E}, 800$ m, 6 July 1984, Beaman et al. 10508 (GH!, K!, L!-image seen); Kampung Bundu Tuhan [559'N 116 32'E], 15 July 1994, Soibeh 809 (K!); E of Kg. Tontolob Ranau Rd. [544'N 116 24 'E], 665 m, 19 June 1980, Leopold E Petrus SAN 92553 (E!, K!, L!-image seen); Sg. Kipolupu, s.a., Soinin et al. SAN 129124 (E!, L!-image seen); TONGOD: Pinangah F. Res. [5²1'N 117³'E], 9 July 1993, Krispinus SAN 136827 (E!, GH!, L!-image seen). PHILIPPINES. LUZON. CAMARINES NORTE: Busch hinter De Freine, Daet [14 $\left.{ }^{\circ} 6^{\prime} \mathrm{N} 122^{\circ} 55^{\prime} \mathrm{E}\right], 11$ June 1903, Hallier s.n. (L!); CAMARINES SUR: Without locality [collected in Camarines Sur according to van Steenis-Kruseman 2017], 1837, Cuming 1478 (E!-image seen); IFUGAO: Kiangan, Lake Ambuaya [16 $\left.47^{\prime} \mathrm{N} 121^{\circ} 7^{\prime} \mathrm{E}\right], 14$ Aug. 1992, Reynoso et al. PPI 7268 (BISH, K!, L-image seen); LAgunA, Los Baños (Mt Maquiling), June July 1917, Elmer 18144 (K!, L!-image seen, P!-image seen, U!-image seen); POLILLO: Island of Polillo, Aug. 1909, Robinson BS 9069 (E!); QUEZON: Tagkawayan, Brgy. Bagong Silang [14 ${ }^{\circ} 3^{\prime} \mathrm{N} 122^{\circ} 25^{\prime} \mathrm{E}$ ], 10 Sept. 1993, Barbon et al. PPI 12224 (BISH, L!); Tayabas, 1837, Cuming 828 (E!-image seen, K!, L!image seen, P!-image seen, W!-image seen); Tayabas, Atimonan, Aug. - Sept. 1904, Whitford 651 (K!, P!image seen); SORSOGON: Irosin (Mt Bulusan),
Oct. 1915, Elmer 14479 (K!, L!-image seen, P!-image seen); Sorsogon Prov., July 1947, Sulit PNH 2632 (L!); MINDANAO. AGUSAN DEL NORTE: Cabadbaran (Mt Urdaneta), Aug. 1912, Elmer 13552 (E!-image seen, K!, L!-image seen, P!-image seen, WRSL!- image seen); DAVAO DEL SUR: Todaya (Mt Apo), Aug. 1909, Elmer 11308 (E!-image seen, K!, L!-image seen, NY!-image seen, US!-image seen); SAMAR. Ins. Samar, s.a., Jagor 932 (M!-image seen, WRSL!-image seen).

HABITAT. Borneo mountain lowland and montane rain forests, Luzon rain forests, Mindanao-Eastern Visayas rain forests, Mindanao montane rain forests, Sulawesi rain forests; alt. $100-1800 \mathrm{~m}$.

CONSERVATION STATUS. Gouania nematostachya is widely distributed, with occurrences in Borneo, Sulawesi and several of the Philippine islands. Over 20 specimens were collected since 1979, from several locations throughout Sabah, and North Sulawesi and Luzon. It is also likely to be less exposed to extinction threats than other Gouania species because of its capacity to grow at higher elevations. With an EOO of over $1,600,000 \mathrm{~km}^{2}$, it is assessed here as of Least Concern (LC), despite extensive clearing for logging and agricultural use in many of its habitats.

PHENOLOGY. Collected in flower in Jan. - May (Sulawesi) and June - Sept. (Borneo, Philippines); collected in fruit (mature, splitting) in May (Sulawesi), July - Aug. (Borneo) and Aug. - Oct. (Philippines).

VERNACULAR NAMES. Lembuhud (Sabah, fide Bakia 217); Solo-solo (Bagobo, fide Elmer 11308).

NOTES. Gouania nematostachya is the only Gouania species in the region with nectar disks lacking narrow lobes opposite the sepals, and is unique in having consistently rugose (wrinkled) nectar disks; it is also recognised by having leaves with usually 40 - 50 fine serrations along the margin. Gouania nematostachya is the only species of the genus known to occur in Borneo. The only other known species of Gouania in the Philippines are G. fimbriata and G. longipedunculata, which have narrow disk lobes opposite the sepals and a leaf margin with usually $15-20$ serrations on each side. Mature fruits of $G$. nematostachya have a smaller height to width ratio than other species of this region (Table 1). Leaves of this species are acuminate, a character that can also be observed in G. leptostachya, which is not known to grow sympatrically with G. nematostachaya and is easily distinguished by its glabrous leaf surface except along veins, fewer secondary veins and crenate leaves with sunken marginal glands (Table 2).

This species and Gouania fimbriata were published by Lauterbach (1922) based on manuscript names and notes by Reissek with no designation of a type specimen. Adherence to the type principle did not become mandatory until 1958, and because a diagnosis is offered for both species, they were validly published. Neither G. fimbriata nor G. nematostachya 
seem to have appeared in the taxonomic literature since Suessengueth's monographic studies of Rhamnaceae (1953). In addition, no other known herbarium specimens besides those examined by Reissek and Lauterbach had hitherto been identified as belonging to either species.

Cuming 1578 held in $\mathrm{W}$ is selected here as the lectotype because it was determined as Gouania nematostachya by both Reissek and Lauterbach, has some open flowers and duplicates are available in several herbaria. The collection year (1837) is not indicated on the label and was inferred using the Cyclopaedia of Malesian Collectors (van Steenis-Kruseman 2017).

About half of the Gouania nematostachya specimens from Borneo and the Philippines were determined as Gouania microcarpa DC. (the rest mostly determined as Gouania sp.). Both species have nectar disks without narrow lobes opposite the sepals, but G. microcarpa has a densely hairy nectar disk and narrower, subentire leaves that are nearly glabrous except along veins. It is only known to occur in India and Sri Lanka, as noted by King (1896). Confusingly, Bhandari \& Bhansali (1990) correctly specify that the disk of G. microcarpa is villous in their key to species of Gouania, but note the disk is glabrous in the species description.

Specimens from the Philippines listed by Rolfe (1885) as Gouania microcarpa also belong to G. nematostachya. Elmer (1915) recognised that Philippine material of G. nematostachya - then not yet published by Lauterbach - was distinct from typical G. microcarpa. He described it as G. microcarpa var. subglabra while noting that it should possibly be considered a new species.

Merrill (1921), Masamune (1942) and Beaman \& Anderson (2004) all list Gouania microcarpa as occurring in Borneo. Illustrative material used by Beaman could be traced in herbaria and is identified here as G. nematostachya.

Lauterbach (1922), while agreeing with King (1896) that Gouania microcarpa s.s. is restricted to India and Sri Lanka, described several taxa without disk lobes opposite the sepals, from New Guinea as varieties of G. microcarpa. Nevertheless, as Lauterbach (loc. cit.) noted, none of the New Guinean taxa have hairy disks. Despite Lauterbach considering the New Guinean specimens to be varieties of $G$. microcarpa, he recognised $G$. nematostachya as a separate species and not an additional variety of $G$. microcarpa.

Although the scope of this revision is restricted to the Philippines and Sundaland, occurrences from Sulawesi are included here to give a complete list for this poorly known species. Sulawesi specimens usually have slightly narrower leaves and were collected in flower and fruit at earlier months of the year.

All but two Bornean specimens of Gouania nematostachya available were collected in Sabah. Amdjah 667 was collected nearby in North Kalimantan. Only Korthals s.n. was collected in the southern half of the island - its leaves are not as conspicuously serrate as other specimens from Borneo, but all other characters suggest it belongs to G. nematostachya. A sampling bias may explain why almost all specimens were collected in such a limited area of the island. More material is available from Sabah, especially collections from SAN, than from other parts of the island. BRUN does not hold any Gouania specimens (Joffre Haji Ali Ahmad, pers. comm.).

In the specimen label notes of Diwol $\mathcal{E} \sigma$ Markus SAN 136538 and de Vogel et al. 5557, the length of the climber is estimated to be $30 \mathrm{~m}$. This would exceed the reported maximum length of $20 \mathrm{~m}$ for any known Gouania species (Medan \& Schirarend 2004; Buerki et al. 2011).

5. Gouania obtusifolia Vent. ex Brongn. (Brongniart 1826: 72). Type: Indonesia, Java, s.a., Delahaye s.n. (lectotype, selected here: G! [G00011846]).

Gouania mauritiana sensu Blume (1826: 1152), non Lam.

Naegelia tomentosa Hassk. (Hasskarl 1852: 114). Type: Indonesia, Java, Jawa Tengah, in Javae centralis montis Ungarang [Ungaran] [7 $7^{\circ} 8^{\prime} \mathrm{S} \quad 110^{\circ} 24 ' \mathrm{E}$ ] declivitatibus sylvestribus prope Medini, s.a., Junghuhn s.n. (lectotype, selected here: L! [L 0484694]).

Gouania javanica Miq. (Miquel 1856: 649) synon. nov. Type: Indonesia, Java, Ronkop [Rongkop], May 1836, Junghuhn s.n. (lectotype, selected here: L! [L 0484693], isolectotype: L!-image seen [L 0484679]).

Woody climber with circinnate tendrils, to at least $18 \mathrm{~m}$ long; girth to at least $2 \mathrm{~cm}$. Indumentum lacking on older branches to dense at distal end of branchlets; stem hairs $0.2 \mathrm{~mm}$ long, curved to tortuous, mostly spreading, almost all reddish-ferruginous, some whitish. Branchlets hollow in the centre, slender, subterete, smooth, with flush longitudinal striations. Stipules soon fugaceous, densely hairy, slightly asymmetric, lanceolate, acuminate, entire to pinnatifid, c. $6 \mathrm{~mm}$ long, medial undivided portion c. $1.5 \mathrm{~mm}$ wide, divisions narrow, c. $0.1 \mathrm{~mm}$ wide, to $0.5 \mathrm{~mm}$ long. Leaves: discolorous, dark green adaxially, paler abaxially, blade shape variable, narrow ovate to wide ovate or oblong, $3.2-12.0 \mathrm{~cm}$ long, $2.0-7.2 \mathrm{~cm}$ wide, chartaceous, apex rounded to acute, base rounded to cordate, cuneate to rounded in distal leaves, margins crenate-serrate, usually 15 - 20 serrations on either side, all along leaf margin, serrations getting closer towards leaf apex, leaf margin with one protruding gland at the apex of each serration, glands crowned with hairs, leaf margin often ciliate; primary vein densely hairy abaxially, hairs mostly appressed, antrorse; secondary veins $5-6(-7)$ pairs, densely hairy abaxially, venation eucamptodromous, basal 
secondary veins reaching margin at c. $60 \%$ of leaf height. angle of divergence from primary vein $25-$ $40^{\circ}$; outer secondary veins branching off basal secondary veins conspicuous, $4-6$; lamina glabrous to abundantly hairy adaxially, more densely along primary and secondary veins; indumentum sparse to abundant abaxially; domatia usually present in vein axils, a foliaceous appendage or tufts of hairs; petiole subterete, flattening distally, channelled, $7-21 \mathrm{~mm}$ long, densely hairy, with glands and foliaceous appendages, especially along edges of channel and near junction with leaf blade, similar to appendages found in domatia. Inflorescence of congested cymes arranged along racemiform thyrses, the distal thyrses often arranged in a panicle, thyrses to $25 \mathrm{~cm}$, with c. 5 flowers in each cyme; bracts narrow-lanceolate, acuminate, c. $4 \mathrm{~mm}$ long, entire to pinnatifid, densely hairy; cymes sessile, pedicels to $1 \mathrm{~mm}$ long, densely hairy. Flowers odourless or faintly scented; hypanthium densely hairy adaxially, indumentum often paler than on inflorescence rachis, sepals triangular, c. $1.2 \mathrm{~mm}$ long, white-cream when fresh, glabrous and keeled adaxially; petals clawed, c. $1.1 \mathrm{~mm}$ long, rugulose adaxially, cream-pale yellow when fresh; stamen filaments flat, subulate, c. $0.9 \mathrm{~mm}$ long, anthers c. $0.2 \mathrm{~mm}$ long, enclosed by petals, nectary disk stellate, glabrous, smooth, diameter excluding lobes c. $1.5 \mathrm{~mm}$, annulus glabrous, raised, tightly sheathing style, disk lobes narrow, tapering, apex entire to slightly notched, usually appressed to sepal lobe when dry, c. $0.9 \mathrm{~mm}$ long ( $3 / 4$ of sepal length); style arms 3 , glabrous. Fruit green when fresh, fruit body sparsely hairy, more densely near apex, drying darker brown than wings, c. $4 \mathrm{~mm}$ high, wings glabrous, $7-10 \mathrm{~mm}$ high, c. $1.2 \times$ height of fruit body, distance between highest points of wings 4 (6) $\mathrm{mm}$, mericarp width $9-12 \mathrm{~mm}$, fruit body width $2.5-3.0 \mathrm{~mm},{ }^{1} / 3$ mericarp width. Seeds $2 \times 2$ $\mathrm{mm}$. obovate, dorsally convex, ventrally concave, shiny brown.

DISTRIBUTION. Malay Peninsula, Sumatra and Java. Map 5. ADDITIONAL SPECIMENS EXAMINED. INDONESIA. JAVA. s.a., Blume s.n. (L!-image seen); 1794 - 1796, Delahaye 2123 (P!-image seen); s.a., Delahaye s.n. (P!-image seen); s.a., Horsfield s.n. (K!); Tjepper, s.a., Horsfield 874 (K!); s.a., Korthals s.n. (L!-image seen); 1803 1804, Leschenault de la Tour s.n. (P!-image seen); s.a. Reinwardt s.n. (L!-image seen); JAWA BARAT: Preanger, Tjikanoeng [Cikawung] [6 $6^{\circ} 37^{\prime} \mathrm{S} 108^{\circ} 2^{\prime} \mathrm{E}$ ], $\pm 25 \mathrm{~m}, 29$ Aug. 1912, Backer 4362 (K!, L!-image seen); Res. Cheribon [Cirebon], G. Tjermai [Mt Ciremai], 900 m, 20 Oct. 1912, Backer 4829 (L!); Res. Preanger, Tjidadap [Cidadap], 1000 m, 12 June 1916, Bakhuizen van den Brink Sr 3895 (L!-image seen, U!-image seen); ibid., Tjibeber [Cibeber], 1000 m, 13 June 1916, Bakhuizen van den Brink Sr 1998 (L!); Preanger, s.a.,
Ploem s.n. (L!); Res. Preanger Reg, Tjadas Malang (bij Tjidadap; I. v. Tjibeber), 1000 m, 11 June 1923, Winckel $1383 \beta$ (L!-image seen, U!-image seen); JAWA TENGAH: Koeripan [Kuripan] [6 $6^{\circ} 56^{\prime} \mathrm{S} 109^{\circ} 53^{\prime} \mathrm{E}$ ], 30 July 1911, Docters van Leeuwen 64 (U-image-seen); Semarang, Kedoengdjati [Kedungjati] $\left[7^{\circ} 9^{\prime} \mathrm{S} 110^{\circ} 37^{\prime} \mathrm{E}\right], 24$ Sept. 1896, Koorders 24983 $\beta$ (L!); Semarang, Karangasem, 15 June 1897, Koorders 28269 $\beta$ (U!-image seen); Banjoemas, Noes Kambangan [Nusa Kambangan] [744'S $108^{\circ} 55^{\prime} \mathrm{E}$ ], 29 May 1899, Koorders 36900 (L!); JAWA TIMUR: E Java, s.a., Reinwardt s.n. (L!, S!-image seen); Sourabava [Surabaya], Aug. 1894, Delahaye 1941 (P!-image seen); Pasoeroean [Pasuruan], Malang, 19 June 1896, Koorders 23447 $\beta$ (L!); Besoeki [Besuki], Poeger [Puger] [8 ${ }^{\circ} 20^{\prime} \mathrm{S}$ $113^{\circ} 28^{\prime} \mathrm{E}$ ], \pm 10 m, 16 Oct. 1895, Koorders $20511 \beta$ (K!, L!-image seen); ibid., 17 Oct. 1895 , Koorders $21768 \beta$ (K!, U!-image seen); ibid., Rogodjampi $\left[8^{\circ} 20\right.$ 'S $114^{\circ} 19^{\prime} \mathrm{E}$ ], \pm 10 m, 25 Aug. 1897, Koorders $28930 \beta$ (K!, L!-image seen); Besoeki, Poeger [Puger] Watangan [8 $24^{\prime} \mathrm{S} 113^{\circ} 30^{\prime} \mathrm{E}$ ], $\pm 5 \mathrm{~m}$, 23 Oct. 1895 , Koorders $21761 \beta$ (L!); Kediri, G. Parang [ $\left.7^{\circ} 50^{\prime S} 111^{\circ} 59^{\prime} \mathrm{E}\right], 16$ June 1896, Koorders 23043ß (K!, L!-image seen); Pasoeroean [Pasuruan], Tangkil, 400 - 500 m, 29 June 1896, Koorders 23642 $\beta$ (K!, L!-image seen); Banyuwangi, 1803 - 1804, Leschenault de la Tour 497 (P!-image seen); Soemberpoetjoeng [Sumberpucung] [8 $8^{\circ} 10^{\prime} \mathrm{S} 112^{\circ} 29^{\prime} \mathrm{E}$ ], June 1918, [Unknown collector] 2724 (WAG!-image seen); PULAU PANAITAN. Prinseneiland, N of mouth of Tjiharashas [Ci Harahas], 2 Sept. 1951, van Borssum Waalkes 282 (K!); SUMATRA. Sumatra, 1880, Forbes 2933a (K!, L!-image seen); ACEH: Near Peureulah [Peureulak] [4 $49^{\circ} \mathrm{S} 97^{\circ} 54^{\prime} \mathrm{E}$ ], sea level, 3 Jan. 1932, Bangham 629 (K!); JAMBI: Sandaranagong [Sanggaran Agung], $2450 \mathrm{ft}[750 \mathrm{~m}$ ], 28 May 1914, Robinson s.n. (K!); LAMPUNG: Lampongs, $400 \mathrm{ft}$ [100 m], 30 June 1880, Forbes 1263 (K!); NW of Kota Agung, $5^{\circ} 23^{\prime} \mathrm{S} 104^{\circ} 25^{\prime} \mathrm{E}, 350-450 \mathrm{~m}, 11$ May 1968, Jacobs 8326 [GH!，K!，L!-image seen]; SUMATERA SELATAN: Tandjong Ning [3 $\left.31^{\circ} \mathrm{S} 103^{\circ} 02^{\prime} \mathrm{E}\right], 1881$, Forbes 2758 (L!, P!-image seen); SUMATERA UTARA: Road from Kaban Dtjake to Kata Tjane [Kabanjahe and Kutacane], 4000 - $5500 \mathrm{ft}[1200-1700 \mathrm{~m}], 17$ Feb. 1932, Bangham 1107 (K!); S Sumatra, Pasumah Lands, s.a., Forbes 2593 (L!); Sibolangit, \pm 500 m, 22 Nov. 1916, Lörzing 4502 (L!); Vicinity of Hoeta Bagasan [Huta Bagasan], Asahan. 7 Sept. 1934 - 4 Feb. 1935, Rahmat Si Boeea 7290 (GH!, L!); MALAYSIA. PENINSULAR MALAYSIA. FEDERAL TERRITORY OF KUALA LUMPUR: Weld Hills F. Res. Kuala Lumpur [39'N 101 $\left.42^{\prime} \mathrm{E}\right], 21$ Jan. 1919, Ahmat C.F. 2345 (K!); Kuala Lumpur, 1899, Ridley 16205 (K!); Kuala Lumpur, Damansara Road [38'N $101^{\circ} 41^{\prime} \mathrm{E}$ ], 20 Dec. 1920, Ridley s.n. (K!); KELANTAN: 20 Jan. 1924, Haniff $\mathcal{E}$ Nur 10052 (L!); Charming, Kelantan R., 8 Feb. 1917, Ridley s.n. (K!); KRABI: Ghirbi, Nong Koh, Jan. 1918, s.c. s.n. [Federat- 


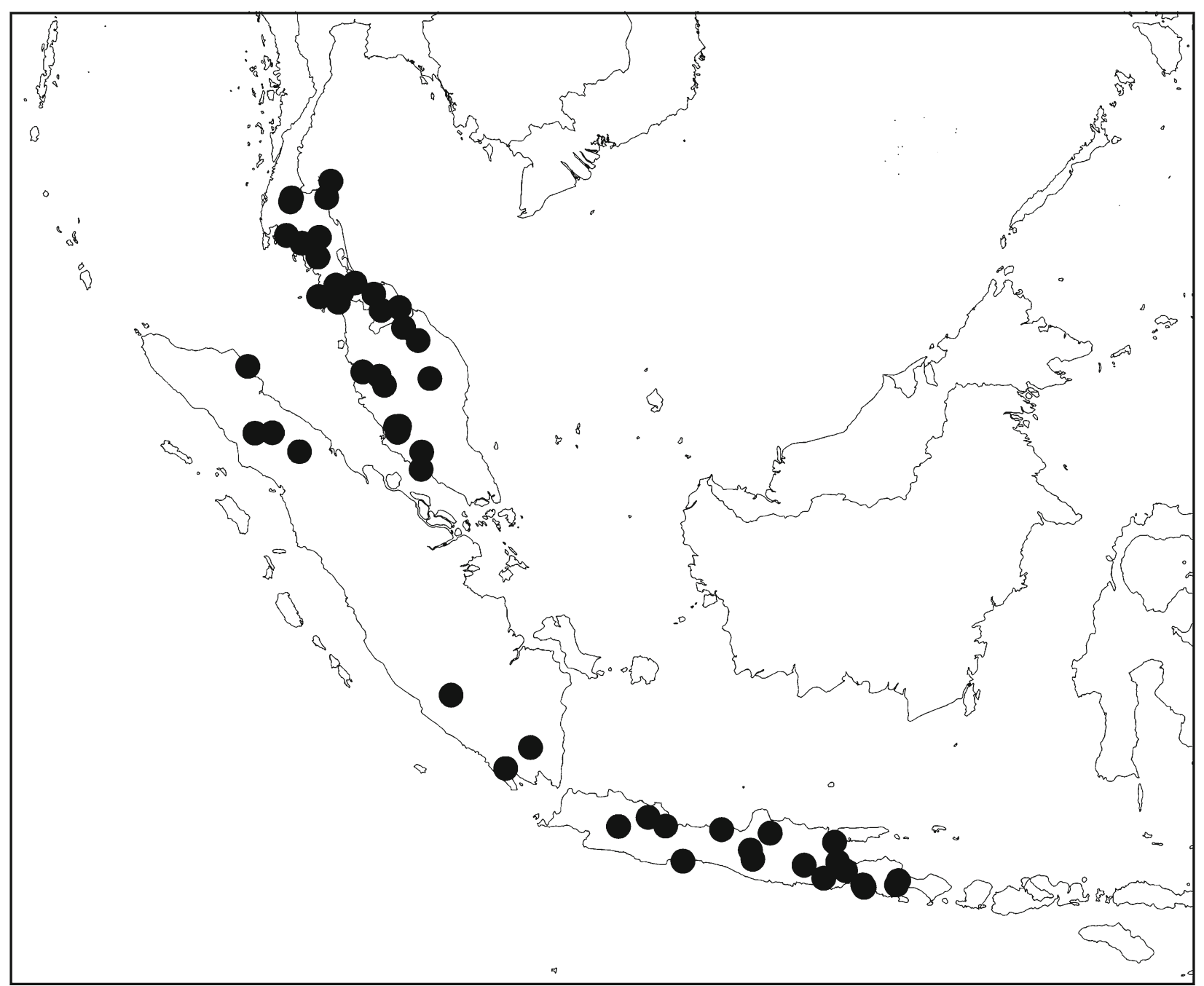

Map 5. Distribution of Gouania obtusifolia $(\bullet)$.

ed Malay States Museum] (K!); MALACCA: 1845, Griffith s.n. (K!); NEGERI SEMBILAN: Johol, 16 Jan. 1917, Ridley s.n. (K!); PAHANG: Taman Negara, S. Tembeling, 2 March 1968, Whitmore FRI 4936 (GH!, K!, L!-image seen); PERAK: near Gunong Booboo [Gunung Bubu], $300-500 \mathrm{ft}$ [100 m - $150 \mathrm{~m}$ ], Dec. 1885, King's collector 8371 (L!); Sunga Ryah, 1880, Kunstler 1009 (E!); ibid., Oct. 1880, King's collector 1046 (K!); Road to Jor, 1908, Ridley 13570 (K!); PERLIS: Up to 5 miles NW of Kangar, 0 - 50 m, 19 Jan. 1983, Davis 69337 (E!); Kangar, March 1910, Ridley 15089 (K!); Mata Ayer Forest Reserve $\left[6^{\circ} 40^{\prime} \mathrm{N} 100^{\circ} 14^{\prime} \mathrm{E}\right], 320 \mathrm{ft}[100 \mathrm{~m}], 19$ Feb. 1981, Wong FRI 31238 (GH!, K!. L!); SELANGOR: Ulu Langat [ $3^{\circ} 9^{\prime} \mathrm{N} 101^{\circ} 42^{\prime} \mathrm{E}$ ], s.a., Boden Kloss s.n. (K!); Templer Park [ $3^{\circ} 17^{\prime} \mathrm{N} 101^{\circ} 38^{\prime} \mathrm{E}$ ], 25 Oct. 1979, Kochummen FRI 26228 (K!, L!-image seen); 12 m.s. Ulu Gombak, roadside [ $3^{\circ} 18^{\prime} \mathrm{N} 101^{\circ} 44^{\prime} \mathrm{E}$ ], 5 Feb. 1969, Teo Ẽ Pachiappan 221 (K!); THAILAND. KRABI: Nai Chong, Khao Khram, 40 m, 18 Jan. 1966, Hansen E。 Smitinand 11978; Klong Tawn Nua [Khlong Thom
Nuea] Subdistr. Kow Pra-Bahng [Khao Pra Bangkhram] Wildlife Sanctuary, headquarters, along Klong (stream), Bahng Dtiew, 50 m, 13 Jan. 2006, Maxwell 06-2 (K!, L!); NAKHON SI THAMMARAT: Thung Song, 12 Feb. 1929, Put 2355 (K!, L!-image seen); Khanom, Mu Ko Thale Tai National Park, Nam Tei Waterfall, 95'24”N 9953'36”E, 160 m, 18 Feb. 2004, Middleton, Phuphat, Pooma Ẽ Williams 3212 (E!, GH!); NARATHIWAT: Ban Tu Gor, Tan Yong Mas [Tanyongmat], $250 \mathrm{ft}$ [100 m], 30 April 1931 (K!, L!image seen, P!-image seen); Weang Distr., Hala-Bala Wildlife Sanctuary, 3rd bridge [ $5^{\circ} 48^{\prime} \mathrm{N} 101^{\circ} 50$ 'E], 133 m, 20 Jan. 2004, Promchua 74 (L!-image seen); SATUN: Nam Rah Village, Toong Ngui [Thung Nui] Subdistr., 25 m, 5 Jan. 1985, Maxwell 85-31 (P!-image seen); Tarutao Island, trail from Puntay Bay to Talo Wao [6 $35^{\prime} \mathrm{N} 99^{\circ} 41^{\prime} \mathrm{E}$ ], 13 Jan. 1981, Congdon 1072 (GH!); SONGKHLA: Saba Yoi, Namtok Sai Khao National Park. Phra Mai Phai Waterfall, 6³8'20"N 101 4'50"E, 135 m, 16 Feb. 2004, Middleton, Phuphat, Pooma E Williams 
3139 (GH!, L-ismage seen); Klong Rhang [Khlong Rang] Hill, foothills $\left[6^{\circ} 55^{\prime} \mathrm{N} 100^{\circ} 36^{\prime} \mathrm{E}\right], 25 \mathrm{~m}, 27$ Jan. 1987, Maxwell 87-108 (L!, P!-image seen); SURAT THANI: Kaw Samui [Ko Samui] [9 $30^{\prime} \mathrm{N} 100^{\circ} 0 ' \mathrm{E}$ ], 14 June 1927, Put 851 (E!-image seen, K!); Phumpin [Phunphin], on road to Takua Pa, $9^{\circ} 5^{\prime} \mathrm{N} 99^{\circ} 0 ' \mathrm{E}, 50 \mathrm{~m}$, 4 April 1987, Soejarto et al. 5874 (GH!, L!); Yan Yao, c. 50 m, 23 Feb. 1930, Kerr 18223 (K!, L!-image seen, P!image seen); TRANG: Na Yong, Na Muen Si, Wat Hua Khao, Santikhunakorn ladder, $7^{\circ} 35^{\prime} \mathrm{N} 99^{\circ} 40^{\prime} \mathrm{E}, 60 \mathrm{~m}$, 24 Dec. 2006, Pooma et al. 6584 (BKF!); YALA: Yala, Feb. 1931, Put 3698 (E! - image seen, K!); Bannang Sata, Wang Bua Thong, 3 Dec. 1966, Sangkhachand 1373 (E!, K!, L! -image seen, P! - image seen).

HABITAT. Tropical moist broadleaf forests, specifically Tenasserim-South Thailand semi-evergreen rain forests, Peninsular Malaysian lowland and montane rain forests, Sumatran lowland and montane rain forests, Western Java lowland and montane rain forests, Eastern Java-Bali lowland and montane rain forests; alt. $0-1200 \mathrm{~m}$.

CONSERVATION STATUS. Gouania obtusifolia is widespread in Sundaland and was collected several times in the Malay Peninsula since 2004. With an EOO of over $1,200,000 \mathrm{~km}^{2}$, it is assessed here as of Least Concern (LC), although its status in Java and Sumatra could be precarious. No Sundaland specimens collected outside of the Malay Peninsula since the 1960s were available for study nor were recent records found in GBIF (2018).

PHENOLOGY. Collected in flower in Jan., May, June and Aug. to Dec.; collected in fruit (mature, splitting) from Jan. to April and Aug. to Oct.

VERNACULAR NAMES. Akar Sibueh (Malay Peninsula, Ridley 1922); Kikoekoeran (Sundanese, fide Bakhuizen van den Brink Sr 1998); Sowagi-aroij (Sundanese, Filet 1876).

NOTES. Gouania obtusifolia is recognised by its reddishferruginous indumentum, coarsely crenate-serrate leaves with usually 15 - 20 serrations on either side, protruding marginal glands and $5-6(-7)$ pairs of secondary veins. The only other species recorded from the Malay Peninsula, Sumatra and Java is G. leptostachya, which has glabrous leaves, except along the veins, shorter, glabrous bracts, stipules with a basal lobule pointing sideways, longer inflorescences and bigger fruits (Table 2). Gouania obtusifolia resembles $G$. fimbriata and $G$. longipedunculata from the Philippines but differs in its coarsely crenateserrate leaves and sessile cymes.

Gouania obtusifolia is a name Etienne Ventenat gave to material Félix Delahaye collected in Java (Brongniart 1826). A single specimen identified as Gouania affinis mauritiana obtusifolia was found in Ventenat's herbarium in $\mathrm{G}$ and is selected as the lectotype here.

Gouania obtusifolia is restricted to Sundaland. However, its synonym G. javanica has been widely used to refer to plants observed in southern China and throughout SE Asia (Chen \& Schirarend 2007; Pitard
1907 - 1912; Wilson 1916). These plants determined as G. javanica but occurring north of the Malay Peninsula share many characters with G. obtusifolia, including stipule and disk characters. Gouania obtusifolia, however, differs in having conspicuously crenate-serrate leaf margins, as noted by Kurz (1871, 1875), Hasskarl (1871) and Lauterbach (1922). It also differs in having a more consistently reddish-ferruginous indumentum, especially on the abaxial surface of sepals (as opposed to more whitish), ovate to oblong leaves (as opposed to consistently ovate) with $5-6(-7)$ pairs of secondary veins (as opposed to $6-7$ ), with a rounded to acute apex (as opposed to attenuate) (D. Cahen pers. obs.). Plants north of the Malay Peninsula commonly referred to as G. javanica best correspond to G. brandisii Hassk. (Hasskarl 1871: 280) as followed by Kress et al. (2003).

A specimen collected by Junghuhn was annoted by Jan-Frits Veldkamp who identified it as a type of Gouania javanica, with both 'holotype' and 'lectotype' circled on the type label (Junghuhn s.n. [L 0484693]). Miquel (1856) possibly used the specimen to describe G. javanica as the label information matches details of the protologue. We lectotypify the specimen here to avoid ambiguity.

Specimens collected by Reinwardt (L! [L.2331537], S!image seen) were originally identified as Gouania ferruginea. M. C. Johnston wrote that "no such name was ever published" on his 1968 identification label for the $\mathrm{S}$ specimen. A protologue could not be retrieved, but the name appears in Filet's dictionary (1876) as "Gouania ferruginea Rwdt.". Pool (2014) recently used the epithet ferruginea for a species found in Guatemala and Honduras.

Gouania obtusifolia was identified as G. mauritiana by Blume (1826), months before it was published as G. obtusifolia by Brongniart (1826) and later G. javanica by Miquel (1856). Kurz (1871) wrote that Blume may have been correct in associating the Java material with G. mauritiana. In 1944, Bakhuizen van den Brink Jr added G. mauritiana identifications on all specimens previously identified as G. javanica or G. obtusifolia held in L. However, G. mauritiana is a species endemic to Réunion (Buerki et al. 2011) and differs from G. obtusifolia in several characters, including acuminate leaves, shorter disk lobes and densely arranged fruits that are completely covered by hairs.

Unusual structures, presumably galls, were observed on two specimens from a collection in Nong Koh, Ghirbi [Krabi], (specimens with no collector name or number). They are indurated, bell-shaped, modified flowers, c. $3 \mathrm{~mm}$ high. The ovary chamber is greatly expanded and the structure is domed by the connivent sepals.

Doubtful and excluded name

Gouania bankana Teijsm. \& Binn. 
This name appears in a catalogue of plants cultivated in the Buitenzorg Botanic Gardens (Teijsmann \& Binnendijk 1866) without reference to a specimen, although there is an indication that the species occurs in Bangka Island.

\section{Dubious specimen}

The following collection has narrow, subentire leaves and its mature (i.e. dehiscing) fruits are smaller than those of Gouania leptostachya and G. obtusifolia.

MALAYSIA. PENINSULAR MALAYSIA. PERAK: Kampar, Gunong Tempurong [4 $\left.{ }^{\circ} 5^{\prime} \mathrm{N} 101^{\circ} 12^{\prime} \mathrm{E}\right], 700 \mathrm{ft}[200$ m], 14 Sept. 1958, Ogata KEP 110168 (K!, L!-image seen).

\section{Species erroneously cited for Sundaland}

Gouania laxiflora Tul. (Tulasne 1857: 130). Type: Madagascar, Antsiranana, Ling-Vatou, s.a., Bernier 207 (holotype P!-image seen [P00386437]).

This species is cited as occurring in "Malakka" by Suessenguth (1953). However, it is only known to be found in mainland Africa (Mozambique and Tanzania), the Mascarenes (Rodrigues Island), the Seychelles (Aldabra, Picard, Cosmoledo), the Comoro Islands (Mayotte), and western Madagascar (Buerki et al. 2011).

\section{Acknowledgements}

The authors thank the curators of the following herbaria for sending their material on loan: BKF, E, GH and L; we thank curators Dr Hans-Joachim Esser (M), Heimo Rainer (W) and Dr Krzysztof Świerkosz (WRSL) for their help finding and digitising material examined by Reissek and Lauterbach; the curatorial team at $\mathrm{G}$ for providing type images; we also thank Heather Lindon for nomenclatural advice.

Open Access This article is licensed under a Creative Commons Attribution 4.0 International License, which permits use, sharing, adaptation, distribution and reproduction in any medium or format, as long as you give appropriate credit to the original author(s) and the source, provide a link to the Creative Commons licence, and indicate if changes were made. The images or other third party material in this article are included in the article's Creative Commons licence, unless indicated otherwise in a credit line to the material. If material is not included in the article's Creative Commons licence and your intended use is not permitted by statutory regulation or exceeds the permitted use, you will need to obtain permission directly from the copyright holder. To view a copy of this licence, visit http://creativecommons.org/ licenses/by/4.0/.

\section{Appendix 1}

\section{Alphabetical index to numbered collections examined}

Ahern's collector Forestry Bureau 2159 (G. fimbriata); Ahmat C.F. 2345 (G. obtusifolia); Amdjah 667 (G. nematostachya); Amin E Francis SAN 120922

(G. nematostachya); Amin $\mathcal{E}$ Francis SAN 121537

(G. nematostachya); Amin $\mathcal{E}$ Suin SAN 123312

(G. nematostachya); Amin et al. SAN 119834

(G. nematostachya).

Backer 1911 (G. leptostachya); Backer 4362 (G. obtusifolia); Backer 4829 (G. obtusifolia); Bakhuizen van den Brink Sr 1998 (G. obtusifolia); Bakhuizen van den Brink Sr 3895 (G. obtusifolia); Bakhuizen van den Brink Sr 4873 (G. leptostachya); Bakia 217 (G. nematostachya); Bangham E。 Bangham 1107 (G. obtusifolia); Bangham E E Bangham 629 (G. obtusifolia); Barbon et al. PPI 12224 (G. nematostachya); Beaman et al. 10508 (G. nematostachya); Burley Ẽ Tukirin et al. 3622 ( $G$. nematostachya).

Chai SAN 25993 (G. nematostachya); Cid 60 (G. longipedunculata); Clemens 26263 (G. nematostachya); Congdon 1072 (G. obtusifolia); Cuming 828 (G. nematostachya); Cuming 973 (G. fimbriata); Cuming 1478 (G. nematostachya); Cuming 1578 (G. nematostachya); Cuming 1623 ( $G$. longipedunculata).

Davis 69337 (G. obtusifolia); de Vogel Ẽ Vermeulen 7170 (G. nematostachya); de Vogel et al. 5184 (G. nematostachya); de Vogel et al. 5557 (G. nematostachya); Delahaye 1941 (G. obtusifolia); Delahaye 2123 (G. obtusifolia); Diwol E Markus SAN 136538 (G. nematostachya); Docters van Leeuwen 64 (G. obtusifolia); Duaneh 429 (G. nematostachya).

Elmer 10301 (G. longipedunculata); Elmer 11106 (G. longipedunculata); Elmer 11308 (G. nematostachya); Elmer 13552 (G. nematostachya); Elmer 14479 (G. nematostachya); Elmer 18144 ( $G$. nematostachya).

Forbes 1263 (G. obtusifolia); Forbes 2593 (G. obtusifolia); Forbes 2933a (G. obtusifolia); Forbes PS 2758 (G. obtusifolia); Foxworthy BS 122411 (G. fimbriata); Fuentes $\mathcal{E}$ de la Rosa PPI 38586 (G. fimbriata).

Gaerlan $\mathcal{E}$ Reynoso PPI 20316 (G. longipedunculata); Garcia E Fernando PPI 25152 (G. fimbriata); Garcia et al. PPI 15057 ( $G$. fimbriata).

Hallier 4625 ( G. longipedunculata); Haniff $\mathcal{E}$ Nur 2911 (G. leptostachya); Haniff $\mathcal{E}$ N Nur 10052 (G. obtusifolia); Hansen E Smitinand 11978 (G. obtusifolia); Horsfield 874 (G. obtusifolia).

Jacobs 8326 (G. obtusifolia); Jagor 932 (G. nematostachya). Kerr, A. F. G. 11654 (G. leptostachya); Kerr, A. F. G. 13830 (G. leptostachya); Kerr, A. F. G. 13944 (G. leptostachya); Kerr, A. F. G. 16503 (G. leptostachya); Kerr, A. F. G. 18223 (G. obtusifolia); King's collector 1046 
(G. obtusifolia); King's collector 6420 ( $G$. leptostachya); King's collector 8371 (G. obtusifolia); Kochummen FRI 26228 (G. obtusifolia); Koorders 16943 B (G. nematostachya); Koorders 18451 (G. nematostachya); Koorders 20511 (G. obtusifolia); Koorders 21761 (G. obtusifolia); Koorders $21768 \beta$ (G. obtusifolia); Koorders $23043 \beta$ ( G. obtusifolia); Koorders 23447 ( $G$. obtusifolia); Koorders $23642 \beta$ (G. obtusifolia); Koorders $24983 \beta$ (G. obtusifolia); Koorders $28269 \beta$ ( G. obtusifolia); Koorders $28930 \beta$ ( G. obtusifolia); Koorders 36900 (G. obtusifolia); Krispinus SAN 136827 (G. nematostachya); Kunstler 1009 (G. obtusifolia).

Lakshnakara 839 (G. obtusifolia); Larsen et al. 41762 (G. leptostachya); Layosa 15015 (G. fimbriata); Leopold Eे Petrus SAN 92553 (G. nematostachya); Leschenault de la Tour 497 (G. obtusifolia); Loher 326 (G. fimbriata); Loher 327 ( G. fimbriata); Loher 328 (G. fimbriata); Loher 5825 (G. fimbriata); Loher 5836 (G. fimbriata); Loher 5841 (G. fimbriata); Lörzing 13270 (G. leptostachya); Lörzing 4502 (G. obtusifolia); Lugas 757 (G. nematostachya); Lugas 786 ( $G$. nematostachya).

Machado 11604 (G. leptostachya); Manayon 69 (G. fimbriata); Martin PNH 33505 (G. fimbriata); Maxwell 06-2 (G. obtusifolia); Maxwell 85-31 (G. obtusifolia); Maxwell 87-108 (G. obtusifolia); Menor PNH 34153 (G. fimbriata); Merrill 1425 (G. fimbriata); Merrill 250 (G. fimbriata); Middleton et al. 3139 (G. obtusifolia); Middleton et al. 3212 (G. obtusifolia); Middleton et al. 4019 (G. leptostachya).

Niyomdahm 1292 (G. leptostachya).

Parkinson 15131 (G. leptostachya); Pooma et al. 6584 (G. obtusifolia); Pooma et al. 6685 (G. leptostachya); Project soma $\mathrm{Em} 17$ (G. leptostachya); Promchua 74 (G. obtusifolia); Put 2355 (G. obtusifolia); Put 3698 (G. obtusifolia); Put 851 (G. obtusifolia).

Rahmat Si Boeea 7290 (G. obtusifolia); Ramos 96 (G. fimbriata); Ramos BS 1749 (G. fimbriata); Ramos BS 39368 (G. longipedunculata); Ramos BS 7117 (G. fimbriata); Reynoso et al. PPI 11785 (G. fimbriata); Reynoso et al. PPI 7268 ( G. nematostachya); Ridley 13570 (G. obtusifolia); Ridley 15089 (G. obtusifolia); Ridley 16205 (G. obtusifolia); Robinson BS 9069 (G. nematostachya). Sangkhachand 1373 (G. obtusifolia); Santisuk 789 (G. leptostachya); Scortechini 1158 (G. leptostachya); Soejarto et al. 5874 (G. obtusifolia); Soibeh 809 (G. nematostachya); Soinin et al. SAN 129124 (G. nematostachya); Sulit PNH 2632 (G. nematostachya); Sulit PNH 13819 (G. longipedunculata); Sulit PNH 17083 (G. longipedunculata); Sulit E' Conklin PNH 17745 (G. longipedunculata); Suwanakoset 1714 (G. leptostachya).

Teo E⿱ Pachiappan 221 (G. obtusifolia).

van Borssum Waalkes 282 (G. obtusifolia); Vanoverbergh 2537 (G. obtusifolia); Vanpruk 766 (G. leptostachya); Vidal y Soler 197 (G. fimbriata); Viola 34 (G. fimbriata).

Wardi 79 (G. nematostachya); Whitford 651

(G. nematostachya); Whitmore E Sidiyasa TCW 3467

(G. nematostachya); Whitmore FRI 4936 (G. obtusifolia);
Winckel $1383 \beta$ (G. obtusifolia); Wong FRI 31238 (G. obtusifolia); Wood $\mathcal{E}^{\circ}$ Wyatt-Smith SAN 4435 (G. nematostachya); Wray Jr 3324 (G. leptostachya); Wray Jr 3346 ( $G$. leptostachya).

Zollinger 1183 (G. leptostachya).

\section{References}

Bachman, S., Moat, J., Hill, A., de la Torre, J. \& Scott, B. (2011). Supporting Red List threat assessments with GeoCAT: Geospatial Conservation Assessment Tool. ZooKeys 150: 117 - 126.

Backer, C. A. \& Bakhuizen van der Brink, R. C. (1965). Flora of Java, Vol. 2. N. V. P. Nord, Groningen.

Beaman, J. H. \& Anderson, C. (2004). The Plants of Mount Kinabalu 5: Dicotyledon Families Magnoliaceae to Winteraceae. Natural History Publications (Borneo), Kota Kinabalu and Royal Botanic Gardens, Kew.

Beentje, H. (2010). The Kew Plant Glossary: An Illustrated Dictionary of Plant Terms. Royal Botanic Gardens, Kew.

Bhandari, M. M. \& Bhansali, A. K. (1990). Rhamnaceae. In: M. P. Nayar, K. Thotathri \& M. Sanjappa (eds), Fascicles of Flora of India 20: 26 - 114. Botanical Survey of India, New Delhi.

Blanco, F. M. (1837). Flora de Filipinas. D. Candido Lopez, Manila.

Blume, C. L. (1826). Bijdragen tot de Flora van Nederlandsch Indie, Vol. 17. Ter Lands Drukkerij, Batavia.

Brandis, D. (1906). Indian Trees: An Account of Trees, Shrubs, Woody Climbers, bamboos and Palms Indigenous or Commonly Cultivated in the British India Empire. A. Constable, London.

Brongniart, A. T. (1826). Mémoire sur la Famille des Rhamnées. Le Jeune, Paris.

Buerki, S., Phillipson, P. B. \& Callmander, M. W. (2011). A Taxonomic Revision of Gouania (Rhamnaceae) in Madagascar and the Other Islands of the Western Indian Ocean (The Comoro and Mascarene Islands, and the Seychelles). Ann. Missouri Bot. Gard. 98(2): 157 - 195.

Cahen, D. \& Utteridge, T. M. A. (2017). Three new species of Ventilago (Rhamnaceae) from South-East Asia. Phytotaxa 307(3): 171 - 182.

\& _ (2018). A synopsis of the genus Smythea (Rhamnaceae). Kew Bull. 73: 2.

Chen, Y.-L. \& Schirarend, C. (2007). Rhamnaceae. In: Z.-Y. Wu, P. H. Raven \& D.-Y. Hong (eds), Flora of China 12: 115 - 168. Science Press, Beijing, and Missouri Botanical Garden Press, St. Louis.

De Candolle, A. P. (1825). Rhamneae. In: A. P. de Candolle (ed.), Prodromus Systematis Naturalis Regni Vegetabilis, Vol. 2: 19 - 42. Treuttel et Würtz, Paris.

Dinerstein, E., Olson, D., Joshi, A., Vynne, C., Burgess, N., Wikramanayake, E., Hahn, N., Palminteri, S., Hedao, P., Noss, R., Hansen, M., Locke, H., Ellis, E., 
Jones, B., Barber, C., Hayes, R., Kormos, C., Martin, V., Crist, E., Sechrest, W., Price, L., Baillie, J., Weeden, D., Suckling, K., Davis, C., Sizer, N., Moore, R., Thau, D., Birch, T., Potapov, P., Turubanova, S., Tyukavina, A., de Souza, N., Pintea, L., Brito, J., Llewellyn, O., Miller, A., Patzelt, A., Ghazanfar, S., Timberlake, J., Klöser, H., ShennanFarpón, Y., Kindt, R., Lillesø, J., van Breugel, P., Graudal, L., Voge, M., Al-Shammari, K. \& Saleem, M. (2017). An Ecoregion-Based Approach to Protecting Half the Terrestrial Realm. BioScience $67(6): 534-545$.

Elmer, A. D. E. (1915). Two Hundred Twenty Six New Species - II. In: A. D. E. Elmer (ed.). Leafl. Philipp. Bot. 8: 2719 - 2883.

Endlicher, S. (1840). Rhamneae. In: S. Endlicher (ed.), Genera plantarum secundum ordines naturales disposita, pp. 1094 - 1105. Beck, Wien.

Fernández-Villar, C. (1880). Rhamnaeae. In: F. M. Blanco (ed.), Novissima Appendix ad Floram Philippinarum, pp. 48 - 49. Plana y C. a , Manila.

Filet, G. J. (1876). Plantkundig Woordenboek voor Nederlandsch-Indië; met korte aanwijzingen van het geneeskundig-en huishoudelijk gebruik der planten, en vermelding der verschillende inlandsche en wetenschappelijke benamingen. De Bussy, Amsterdam.

Gamble, J. S. (1935). The Flora of the Presidency of Madras. Adlard \& Son, Ltd., London.

GBIF (2018). GBIF Occurrence Download. Available from: https://doi.org/10.15468/dl.vjouws Accessed $17 \mathrm{Ju}-$ ly 2018.

Hasskarl, J. C. (1852). Beiträge zur Flora von Java und Sumatra. Flora 35(8): 113 - 118.

(1871). Ueber einige neue und unvollkommen bekannte Indische Pflanzen von Sulpiz Kurz, Conservator des Herbariums zu Calcutta, Flora 54: 276 - 284.

Heyne, K. (1922). De nuttige planten van NederlandschIndië, tevens synthetische catalogus der verzamelingen van het Museum voor Technische- en Handelsbotanie te Buitenzorg, Deel III. Ruygrok \& Co., Batavia.

Hickey, L. J. (1979). A revised classification of the architecture of dicotyledonous leaves. In: C. R. Metcalfe \& L. Chalk (eds), Anatomy of the dicotyledons. Second Edition. Volume 1. Systematic anatomy of the leaf and stem, pp. 25 - 39. Oxford Science Publications, Oxford.

Hooker, J. D. (1862). Rhamnaceae. In: G. Bentham \& J. D. Hooker (eds), Genera Plantarum, Vol. 1: 371 386. Reeve \& Co., London.

IUCN (2012). IUCN Red List Categories and Criteria: Version 3.1, Second edition. IUCN, Gland and Cambridge.

\& UNEP-WCMC (2018). The World Database on Protected Areas (WDPA). Cambridge, UK. Available from: www.protectedplanet.net (accessed: 17 July 2018).

King, G. (1896). Materials for a flora of the Malayan Peninsula. J. Asiat. Soc. Bengal, Pt. 2, Nat. Hist. 65 (2): $339-516$.
Kress, W. J., DeFilipps, R. A., Farr, E. \& Daw, Y. Y. K. (2003). A checklist of the trees, shrubs, herbs, and climbers of Myanmar. Contr. U.S. Natl. Herb. 45: 1- 590.

Kurz, W. S. (1871). On some new or imperfectly known Indian Plants. J. Asiat. Soc. Bengal, Pt. 2, Nat. Hist. 40: $45-78$.

(1875). Contributions towards a knowledge of the Burmese flora (Part II). J. Asiat. Soc. Bengal, Pt. 2, Nat. Hist. 44: 128 - 190.

(1877). Rhamnaceae. In: W. S. Kurz (ed.), Forest flora of British Burma, Vol. 1: 261 - 270. Office of the Superintendent of Government Printing, Calcutta.

Lamoreux, J. (2001). Southeastern Asia: Luzon Island in the Philippines. Available from: http:// www.worldwildlife.org/ecoregions/im0123 Accessed 17 July 2018.

Lauterbach, C. (1922). Die Rhamnaceen Papuasiens. Bot. Jahrb. Syst. 57: $326-340$.

Masamune, G. (1942). Enumeratio Phanerogamarum Bornearum. Taihoku University, Taiwan.

Medan, D. \& Schirarend, C. (2004). Rhamnaceae. In: K. Kubitzki (ed.), The Families and Genera of Vascular Plants, Vol. 6: Celastrales, Oxalidales, Rosales, Cornales, Ericales, pp. 320 - 338. Springer Verlag, Berlin, Heidelberg.

Merrill, E. D. (1915). Genera and species erroneously credited to the Philippine flora. Philipp. J. Sci. C 10: $171-195$.

(1918). Rhamnaceae. In: E. D. Merrill (ed.), Species Blancoanae, pp. 243 - 245. Bureau of Printing, Manila. (1921). A bibliographic enumeration of Bornean Plants. J. Straits Branch Roy. Asiat. Soc., special number: 1 - 637 .

(1923). Rhamnaceae. In: E. D. Merrill (ed.), An Enumeration of Philippine Plants, Vol. 2, Fasc. 5: 521 526. Bureau of Printing, Manila.

Miquel, F. A. W. (1856). Flora van Nederlandsch Indië, Vol. 1. C. G. van der Post, Amsterdam.

(1860). Flora van Nederlandsch Indië. Erste bijvoegsel. Sumatra, zijne plantenwereld en hare voortbrengselen. C. G. van der Post, Amsterdam.

Moritzi, A. (1846). Rhamnaeae. In: A. Moritzi (ed.), Systematisches Verzeichnis der von H. Zollinger in den Jahren 1842 - 1844 auf Java gesammelten Pflanzen, p. 20. Fr. X. Zepfel, Solothurn.

Morrison, J. (2001a). Greater Negros-Panay Rain Forests. Available from: http://www.worldwildlife.org/ ecoregions/im0114 Accessed 17 July 2018.

(2001b). Mindanao-Eastern Visayas Rain Forests. Available from: http://www.worldwildlife.org/ ecoregions/im0129 Accessed 17 July 2018.

(2001c). Mindoro rain forests. Available from: http://www.worldwildlife.org/ecoregions/im0130 Accessed 17 July 2018.

Pitard, C.-J. (1907 - 1912). Rhamnacées. In: H. Lecomte (ed.), Flore générale de l'Indo-Chine, Vol. 1: 908 - 934. Masson et Cie., Paris. 
Pool, A. (2014). Taxonomic Revision of Gouania (Rhamnaceae) for North America. Ann. Missouri Bot. Gard. 99(3): 490 - 552.

Reissek, S. (1861). Rhamneae. In: C. F. P. von Maritius (ed.), Flora Brasiliensis, Vol. 11 (1): 82 - 116, t. 24 - 41. Lipsiae apud Fried. Fleischer in Comm., Munich.

Richardson, J. E., Fay, M. F., Cronk, Q. C. B., Bowman, D. \& Chase, M. W. (2000a). A Phylogenetic Analysis of Rhamnaceae using rbcL and trnL-F Plastid DNA Sequences. Amer. J. Bot. 87: 1309 - 1324.

\& Chase, M. W. (2000b). A revision of the tribal classification of Rhamnaceae. Kew Bull. 55: $311-340$.

Ridley, H. N. (1922). Rhamnaeae. In: H. N. Ridley (ed.), Flora of the Malay Peninsula, Vol. 1: 461 - 468. L. Reeve, London.

Rolfe, R. A. (1885). Supplementary list of Philippine Plants. J. Bot. 23: $209-216$.

Roxburgh, W. (1795). Plants of the Coast of Coromandel, Vol. 1. W. Bulmer \& Co., London.

Stafleu, F. A. \& Cowan, R. S. (1981). Taxonomic literature. A selective guide to botanical publications and collections with dates, commentaries and types. Vol. III: Lh - O, Second edition. Bohn, Scheltema and Holkema, Utrecht and Antwerp.

van Steenis, C. G. G. J. (1950). The delimitation of Malaysia and its main plant geographical divisions. In: C. G. G. J. Van Steenis (ed.), Flora Malesiana, Ser. 1, Vol. 1: lxx - lxxv. Noordhoff-Kolff N.V., Djakarta.

van Steenis-Kruseman, M. J. (2017). Cyclopaedia of Malesian Collectors. Available from: http://
www.nationaalherbarium.nl/FMCollectors / Home.htm Accessed 17 July 2018.

Suessenguth, K. (1953). Rhamnaceae. In: A. Engler \& K. Prantl (eds), Die Natürlichen Pflanzenfamilien Zweite Auflage Band 20d: 1 - 173. Duncker and Humbolt, Berlin.

Teijsmann, J. E. \& Binnendijk, S. (1866). Catalogus plantarum quae in Horto botanico bogoriensi coluntur. Lands-Drukkerij, Batavia.

Tulasne, L. R. (1857). Florae Madagascariensis Rhamneae. Ann. Sci. Nat., Bot., Sér. 4, 8: 120 - 126.

Vidal, S. (1886). Revision de Plantas Vasculares Filipinas, p. 92. M. Perez, Manila.

Wikramanayake, E. D., Dinerstein, E. \& Loucks, C. J. (2002). Terrestrial ecoregions of the Indo-Pacific: $a$ conservation assessment, Vol. 3. Island Press, Washington, D.C.

Wilson, E. H. (1916). Rhamnaceae. In: C. S. Sargent (ed.), Plantae Wilsonianae, Vol. 2: 209 - 254. University Press, Cambridge.

Woodruff, D. S. (2003). Neogene marine transgressions, palaeogeography and biogeographic transitions on the Thai-Malay Peninsula. J. Biogeogr. 30(4): $551-567$.

\section{Publisher's Note}

Springer Nature remains neutral with regard to jurisdictional claims in published maps and institutional affiliations. 